Portland State University

PDXScholar

$11-5-1993$

\title{
Comparative Analysis of Resettlement Policies in Third World Countries
}

Abrahim Jawad Al-Khalisi

Portland State University

Follow this and additional works at: https://pdxscholar.library.pdx.edu/open_access_etds

Part of the Urban Studies and Planning Commons

Let us know how access to this document benefits you.

\section{Recommended Citation}

Al-Khalisi, Abrahim Jawad, "Comparative Analysis of Resettlement Policies in Third World Countries" (1993). Dissertations and Theses. Paper 4609.

https://doi.org/10.15760/etd.6493

This Thesis is brought to you for free and open access. It has been accepted for inclusion in Dissertations and Theses by an authorized administrator of PDXScholar. Please contact us if we can make this document more accessible: pdxscholar@pdx.edu. 


\section{DISSERTATION APPROVAL}

The abstract and dissertation of Abrahim Jawad Al-Khalisi for the Doctor of

Philosophy in Urban Studies was presented November 5, 1993 and accepted by the dissertation committee.

APPROVALS:

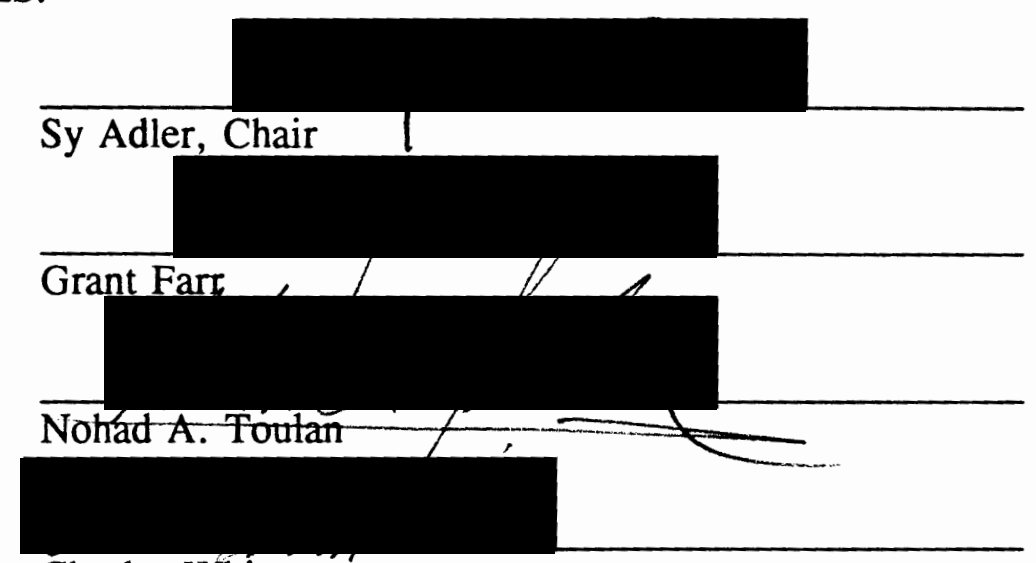

Charles White

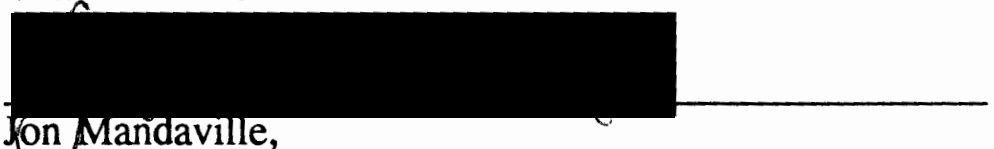

Jon Mandaville,

Representative of the Office of Graduate Studies

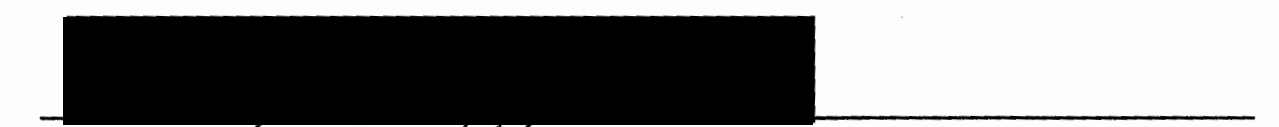

Nancy J. Chapman, Coordinator, Ph.D. Program in Urban Studies

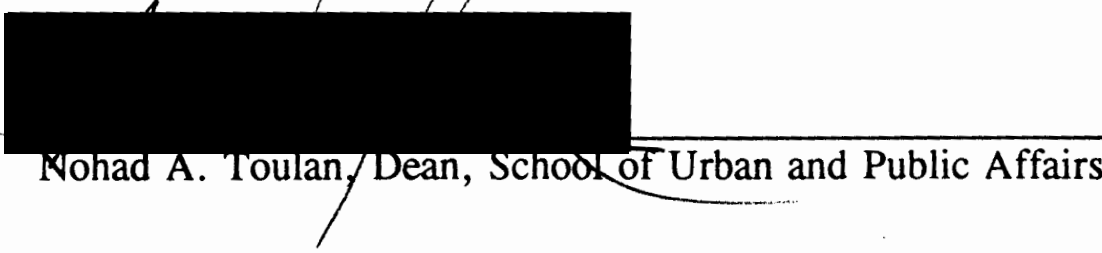

$* * * * * * * * * * * * * * * * * * * * * * * * * * * * * * * * * * * * * * * * * * * * * * * * * * * * * * * * * * *$

ACCEPTED FOR PORTLAND STATE UNIVERSITY LIBRARY

by
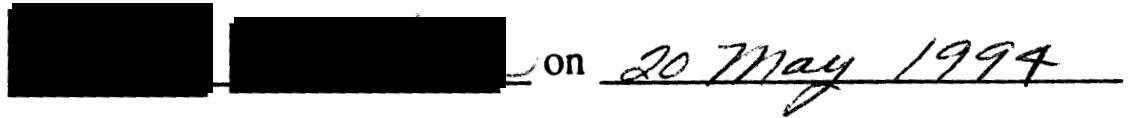


\section{ABSTRACT}

An abstract of the dissertation of Abrahim Jawad Al-Khalisi for the Doctor of Philosophy in Urban Studies presented November 5, 1993.

Title: Comparative Analysis of Resettlement Policies in Third World Countries

Settlement policy in the Third World has been stimulated by the availability of public land. This availability of public land has prompted many Third World countries to adopt policies or schemes called resettlement, transmigration, or land development. These have been presented as potential means for addressing numerous agendas held by Third World countries. Settlement policies have been used to increase agricultural production and make idle land productive. Spatial imbalances of population distribution have been addressed via settlement policies. For national security, settlement policies have been used to exploit frontier lands. Solutions to serious political problems including lack of agricultural selfsufficiency, poverty, landlessness, and unemployment have been sought through settlement policies.

Huge amounts of financial resources have been invested in Third World planned settlements, however, their performance has not been very encouraging. If not completely abandoned by settlers, the settlements gave officials, planners, and policy makers cause for serious concern. For the most 
part, settlements have been costly relative to the number of settlers. In many 2 instances, agricultural productivity was low.

I have presented comparative case studies of land settlement policies which examine the factors that accounted for the success or failure of resettlement projects. I examined the resettlement projects from the point of view of the settlers in relation to the objectives of the policy makers.

This study reports the findings of case studies concerning Iraq, Somalia, Ethiopia, the United Republic of Tanzania, Indonesia, Malaysia, the Philippines, and Israel. A comparative analysis of land settlement policies in Third World nations with varying political, social, and economic conditions is presented.

It will be shown that land settlement policies in Third World countries, by and large, failed to reach objectives and are not now viewed as viable options for land development. 
COMPARATIVE ANALYSIS OF RESETTLEMENT POLICIES IN THIRD WORLD COUNTRIES

\author{
by \\ ABRAHIM JAWAD AL-KHALISI
}

A dissertation submitted in partial fulfillment of the requirements for the degree of

DOCTOR OF PHILOSOPHY

in

URBAN STUDIES

Portland State University

1993 
TABLE OF CONTENTS

PAGE

LIST OF FIGURES

$\mathrm{vi}$

\section{CHAPTER}

I INTRODUCTION $\ldots \ldots \ldots \ldots \ldots \ldots \ldots \ldots \ldots \ldots \ldots \ldots \ldots$

Questions Addressed $\ldots \ldots \ldots \ldots \ldots \ldots \ldots \ldots \ldots, 3$

II IMPLEMENTATION OF DEVELOPMENT PROJECTS IN

THIRD WORLD COUNTRIES . . . . . . . . . . . 5

The Context of Policy .................... 8

Politics and Implementation in Third World Countries 10

III INTRODUCTION TO CASE STUDIES ............. 16

IV DUJAILA LAND SETTLEMENT IN IRAQ $\ldots \ldots \ldots \ldots \ldots 20$

Project Description .................... 23

The Dujaila Land

Water Policy of the Project

The Administration and Facilities

Dujaila Project Population and Social Life

Dujaila's Homestead

Soils

Crop Rotation Practice

Livestock in Dujaila

Settler Adjustment

The Success and Failure of the Dujaila Project...... 39 
$\mathrm{V}$ LAND SETTLEMENTS IN THE REPUBLIC OF TANZANIA . 40

The Colonial Settlement Era . . . . . . . . . . . . . 41

Post-Colonial Settlement . . . . . . . . . . . . . . 41

Spontaneous Settlements .................. 42

Objectives of Ujamaa

Implementation of Ujamaa

Structure of Ujamma Villages

Formation of Ujamma Villages and

Population Redistribution

Population Redistribution ................ 47

Agricultural Production in the Settlements ........ 48

Rural Income Distribution . . . . . . . . . . . . . . . 49

Villagization and Basic Services .................. 49

Cost and Benefits of Land Settlements . . . . . . . . . . 50

Conclusion .......................... 51

VI LAND SETTLEMENT IN ETHIOPIA $\ldots \ldots \ldots \ldots \ldots \ldots \ldots$

Objectives of Planned Settlement ............. 58

The Settlement Process

The Settlement Model

The Settlements Scheme Achievement . . . . . . . . . . 61

Conclusion ........................ 62

VII RESETTLEMENT OF NOMADS IN SOMALIA . . . . . . . . 64

The Resettlement Policy ...................... 65

The Nomad Resettlement

Organization of the Settlements

Settler Characteristics and Training

Income and Work Incentives in the Settlements

Assessment of Social Structure and Infrastructure . . . . 68

Population Redistribution

Conclusion 
VIII LAND SETTLEMENT IN MALAYSIA $\ldots \ldots \ldots \ldots \ldots 72$

Transfer of Land Ownership and Development ...... 73

Group Settlement Schemes ............... 75

Fringe Schemes ................... 76

Implementation and Settler Selection . . . . . . 77

Development of Land

Pattern of Settlement Development

Land Development Achievements ............. 79

Conclusion ...................... 80

IX LAND SETTLEMENTS IN THE PHILIPPINES . . . . . . . 81

Settlement Policy History . . . . . . . . . . . . . 81

Conclusions and Policy Implications . . . . . . . . . 84

$x \quad$ SETTLEMENTS IN ISRAEL $\ldots \ldots \ldots \ldots \ldots \ldots \ldots \ldots \ldots . \ldots 6$

OTZEM Settlement .................. 87

Type of Farming on the Settlement

Land Allocation

The Settlers' Income

Participation in Production

Demography

Noam Settlement. . . . . . . . . . . . . . . . ..... 91

Size of the Settlement

Noam Settlers

Type of Settlement Production

From Administered to Self-Managed Communities:

The Model in the Lakhish Experience . . . . . . . . . 94

Selection of Settlers

The External Supporting Team

Stages in the Transition from Administered to

Self-Managed Community............... 98

Stage of Administration of External Agencies

Stage of Transition

Stage of Consolidation and Weaning 
Conclusion.............................. $\quad{ }^{\mathrm{v}}$

XI LAND SETTLEMENTS IN INDONESIA . . . . . . . . . . . . 101

History of Transmigration Policy ............... 101

Renewed Interest in Transmigration ............. 103

Selection of Transmigrants

Settlement Site Selection

Land Preparation

Migrant Assistance

Regional Development

Conclusion............................. 109

XII COMPARISON OF SETTLEMENT PROJECTS .......... 111

Achievement of Settlement Objective ............. 111

Population Redistribution

Settlements and Development of New Areas

Land for the Landless

Regional Development

Agricultural Development

Improved Welfare of the Settlers

Settler Incomes

Social Services

Problems Confronting Settlement Programs ........ 117

Abandonment of Settlement Projects

Lack of Nonagricultural Employment and Second Generation Problems

Social Tensions Between Settlers and Original Populations

Ecological Problems

XIII SETTLEMENT SUCCESS OR FAILURE ............. 120

Planned and Spontaneous Settlements ............ 124

XIV CONCLUSION ............................... 126

REFERENCES CONSULTED $\ldots \ldots \ldots \ldots \ldots \ldots \ldots \ldots \ldots \ldots \ldots, 130$ 


\section{LIST OF FIGURES}

FIGURE

PAGE

1. Location of Dujaila Land Settlement ............ 21

2. Plan of Dujaila Land Settlement............... 24

3. Dujaila Settlement Pattern ................. 30

4. Typical Land Use on a Dujaila Farm ............. 34

5. Fruit Garden Layout on Dujaila Farm ............ 37 


\section{CHAPTER I}

\section{INTRODUCTION}

The main purpose of this study is to analyze the implementation of land settlement policies in the context of the socioeconomic, historical and political factors associated with rural unemployment and poverty. The creation of jobs for people in rural areas is one of the central components of national development.

As population continues to increase in the Third World, the demand for rural land increases. The increase in land demand may be attributed to the pursuit of the development objectives of population redistribution, increased agricultural production, the alleviation of agrarian poverty, and rising standards of living. Many developing countries have developed schemes labeled as resettlement, land colonization, and land development in order to pursue these objectives.

Despite the substantial amounts that have been invested in such schemes, their performance has not been very encouraging. They have caused serious concern to settlement officials and policy makers in almost all parts of the developing world. They have been costly relative to the numbers of people settled, have shown low productivity, and in some cases have had a high rate of desertion. Many studies have been conducted concerning this subject, including an important one done through the International Labour Organization (1977) which examined the experiences of Indonesia, Malaysia, 
Somalia, Ethiopia, and Tanzania.

Little is known about the actual causes of success and failure of resettlement schemes. It is not even clear whether such settlements are, in fact, an effective way of settling large numbers of people on virgin or reclaimed land.

Settlement policies have been used to increase agricultural production and make idle land productive. Spatial imbalances of population distribution have been addressed via settlement policies. For national security, settlement policies have been used to exploit frontier lands. Solutions to serious political problems including lack of agricultural self-sufficiency, poverty, landlessness, and unemployment have been sought through settlement policies.

This study reports the findings of case studies concerning Iraq, Indonesia, Malaysia, the Philippines, Somalia, Ethiopia, the Republic of Tanzania, and Israel. A comparative analysis of land settlement policies in Third World nations with varying political, social, and economic conditions is presented.

The choice to study land settlement projects in the aforementioned Third World countries emerged from an initial interest in programs in post World War Two Iraq. For purposes of comparison, other Third World countries with similar social, economic, and cultural conditions were chosen for analysis. The environmental and ecological conditions of the other countries were also factors contributing to their selection for case studies.

Huge amounts of financial resources were invested in these countries' planned settlements, however, their performance was not very encouraging. If not completely abandoned by settlers, the settlements gave officials, planners, and policy makers cause for serious concern. For the most part, settlements were costly relative to the number of settlers. In many instances 
agricultural productivity was low.

It will be shown that land settlement policies in Third World countries, by and large, failed to reach objectives and are not now viewed as viable options for land development.

\section{QUESTIONS ADDRESSED}

Following A. S. Oberai (1988) in his edited collection, Land Settlement Policies and Population Redistribution in Developing Countries, I will address these questions:

1. Have settlement schemes achieved their stated objectives?

2. How do income and productivity in settlements compare with other areas?

3. To what extent have planned settlement schemes succeeded in improving settlers' socioeconomic well-being?

4. What are the principal factors that contribute to the success or failure of settlement schemes?

5. What lessons can be learned and applied to future settlement schemes?

I propose to define the success of settlement policy in terms of the situation of poor, unemployed, or landless people before and after policy implementation. The beneficiaries must be better off, economically and socially - including health and education - than before they joined the settlement - and soon. I believe that all human beings need more than to eat and sleep. Life becomes more complicated over time. In many cases, land settlement became an artificial bandage, placed here and there in most Third World countries, to give the false impression that governments were 
working to improve the situation of poor people. Within a few years, all such work and expenditures disappeared, and sometimes the condition of the settlers was worse than before, to say nothing of the physical scars left on the land. If there is to be any development and improvement, the political and economic systems of the Third World countries, especially the richer countries, must permit people to choose freely their own governments and representatives and negotiate development democratically and fairly with the people, with a fair distribution of wealth according to the population's initiatives. In most richer Third World countries, people are suffering, there is poverty, excess government control, executions, jailings and torture, and disappearances. 
CHAPTER II

\section{IMPLEMENTATION OF DEVELOPMENT PROJECTS IN THIRD WORLD COUNTRIES}

Implementation is especially central to politics in the Third World countries of Asia, Africa and the Middle East. Its centrality to the political environment of these countries makes it worthy of investigation and analysis. Implementation involves more than mechanical translations of goals into routine procedures; it involves basic questions about conflict, decision making and who gets what in society (Grindle 1980).

Many researchers have attempted to define the parameters of a general process of implementation by cataloging the variables that intervene in it and some of the relationships among such variables. According to Grindle (1980) there are two questions about implementation in general that are related to specific conditions surrounding the execution of public programs in the Third World countries. First, what effect does the content of public policy have on its implementation, and second, how does the political context of administrative action affect policy implementation. Implementation is an ongoing process of decision-making by a variety of actors, the ultimate outcome of which is determined by the content of program being pursued and the interaction of the decision-makers within a given administrative context.

The following case studies illuminate the importance of the content and 
contextual variables in the implementation process of land settlement policies in Third World countries. The case studies provide insights to how and why content and contextual variables intervene in the implementation process. The generalizations about the implementation process of land settlement policies gleaned from these case studies may be useful for analysis of other implementation processes. Yet before developing the generalizations from these case studies it is important to define more explicitly what is meant by implementation, content, and context.

In general, the task of implementation is to make a link that allows the goals of public policies to be realized as outcomes of government activity. It involves the creation of a policy delivery system. Thus, public policies of goals, objectives, and means are translated into action programs that aim to achieve the ends stated in the policy. Then, so that different programs could be developed in response to the same policy goals, action programs themselves may be disaggregated into more specific projects to be administered.

The purpose of such programs are to cause a change in the policy environment. The distinction between policy and program implies that policy implementation is a function of program implementation and is dependent upon its outcome. It is evident from such an interpretation of policy implementation that it involves study and analysis of action programs for achieving broader policy goals. This was apparent in the objectives Third World governments hoped to achieve, which included; greater agricultural productivity, low income housing, rural development, raising the standard of living for the poor, employment, health, and education. The Third World governments sought to achieve these objectives through land settlement programs; considered a specific program for achieving these goals. 
The content of public programs and policies is an important element in determining the outcome of implementation initiatives. Implementation of various programs for instance, to the extent that public actions seek to make changes in social, political, and economic relationships, they generally stimulate a great deal of opposition from those who's interests are threatened by them. An example is landowners who oppose agrarian reform measures.

A distinction can also be made between programs providing collective benefit, which may mobilize more particularistic demands at the implementation stage. Programs establishing collective goods such as the provision of light and water, health services in rural areas, and in urban slum neighborhoods may be readily implemented in the Third World because the compliance of groups or localities affected will tend to be forthcoming with a minimal amount of conflict (Hadden 1974). A program with great benefits such as housing may create conflict and competition among those seeking to benefit from them and may be more difficult to execute as intended (Rottenbag 1980). Differences in the degree of behavior change the program for its intended beneficiaries is another way the content of policy affects its implementation.

The introduction of new technologies for agricultural development is a commonly cited example of programs requiring considerable adaptation and participation by the recipients. In constrast, providing housing for low income people may require little change in the behavior patterns. In the case of programs that are designed to achieve long-range objectives, implementation may be more difficult than in circumstances where the advantages are immediately known by the beneficiaries. As an example, the small support and participation that preventative health programs are able to elicit from target populations in Third World countries often stands in stark 
contrast to the receptiveness of potential recipients of land titles in rural settlements. This is because the latter policy directly affects residents' economis situation and sense of security.

The content of various policies also dictates the site of implementation. An example is housing or agricultural policy that depends upon a network of widely dispersed, decision units whose responsibilities are also organizationally dispersed. Local and national level agents of the ministry of agriculture, agrarian reform department, community development agency, public works ministry, and the agricultural credit bank may all be implicated as implementors of a rural development policy in any given country. As the site of implementation becomes more dispersed, geographically and organizationally, the task of executing a particular program becomes more difficult, given the increase of decisional units involved (Pressman and Wildavsky 1980).

\section{THE CONTEXT OF POLICY}

As the preceding discussion indicates, the policy content is an important factor because of the real or potential effect it may have on a given social, political and economic setting. Therefore, it is necessary to consider the context or environment in which administrative action is pursued. The implementation is an ongoing process of decision making involving a variety factors affecting the allocation of resources. One of these factors may be the attempt by certain people or interest groups to influence decisions. Those who might be involved in the implementation of any particular program would include national level planners; regional and local politicians; economic interest groups, especially at the local level; recipient 
groups; and bureaucratic implementors at middle and lower levels. The people and groups may be intensely or marginally involved in implementation, depending on the content of the program and the form in which it is administered. Each may have special interest in the program, and each may seek to get it by their demand on allocation procedures. The goals of such actors will be in direct conflict with each other and the end result of this conflict and consequently, who gets what, will be decided by the strategies, resources, and power position of each of the individuals involved.

What is implemented may thus be the result of political maneuvers by interest groups competing for scarce resources, the response of implementing officials, and the actions of political elites, all interacting within given institutional contexts. In such conditions, analysis of the implementation of specific programs may imply assessing the power capabilities of the individuals, their interests and the strategies for achieving them. This may in turn facilitate assessing the potential for achieving policy and program goals (Anderson 1972).

In achieving such goals officials confront two minor problems. First, officials must address the problem of how to obtain compliance with the ends enunciated in the policy (Kaufman 1973). They must turn the opposition of those who may be harmed by the programs into acceptance of them, and they must keep those who are excluded but who wish to acquire benefits from subverting them. Obtaining this kind of compliance may mean much bargining accomodation and again considerable conflict. But if overall policy goals are to be realized, the resources traded to acquire compliance must not jeopardize the impact or focus of specific programs.

This first problem is exacerbated by special interests and groups competing for scarce resources, the response of implementing officials, and 
the action of political elites, all interacting within given institutional contexts. Analysis of the implementation of specific programs may imply assessing the power capabilities of the individual, their interests, and the strategies for achieving them. This in turn may facilitate assessing the potential for achieving policy and program goals (Anderson 1972).

The second problem of achieving policy and program goals within a specific environment is that of responsiveness. Bureaucracies must be responsive to the needs of those to benefit in order to serve them the best way possible. In addition, without a great deal of responsiveness during implementation, public officials are deprived of information to evaluate program achievement and of support important to its success. In many cases, however, responsiveness may mean that policy goals are not achieved because of the intervention of the individuals or groups. Either in order to acquire specific types of goods or services in greater amounts, or to obstruct the accomplishment of particular programs that may not be as beneficial to them. The problem for policy administrators is to ensure an adequate degree of responsiveness to provide flexibility, support, and feedback, while at the same time maintaining enough control over the distribution of resources to achieve the stated goals (Emmerson 1974).

\section{POLITICS AND IMPLEMENTATION IN THIRD WORLD COUNTRIES}

Political participation and competition in implementing public policies in Third World countries may be viewed as by-products of the political systems themselves. Distance and remoteness, inaccessibility of the policy making process to most people, and extensive competition caused by widespread need and very scarce resources are just few of the contextual 
factors affecting the implementation process. However, in many Third

World countries, the output stage of the implementation process is where the demands of individual and collective interests emerge and conflict resolved (Weiner 1962).

In the Third World countries, political parties are more important as mechanisms by which elites control mass followings than as means by which interests are articulated from below to government leadership. This is true in regimes in which single or dominant parties direct the political stage. In other countries parties may be vehicles for the personal ambitions of individual politicians who have no real commitment to achieving goals beyond obtaining government jobs and distributing them to loyal followers (Lande 1973).

Interest groups may be similarly ineffective as structures for presenting collective demands to the political leadership. Interest associations are frequently captive organizations of ruling parties. They exist only at the power and indulgence of the government, or like parties are formed for the single purpose of protecting the political interests of their leadership. Beside these problems, other constraints on their aggregative capacities include limited communication facilities, dispersed potential membership, and lack of education and experience. These characteristics mean that frequently there are few organizations that are capable of representing the interests of broad categories of citizens and formulating policies responsive to their particular needs. Those few that are effective in this role tend to be the wealthy and powerful groups such as bankers, landowners and industrialists.

Related to the weakness of interest aggregating mechanisms in Third World countries is the frequently encountered attitude of leaders in both political and administrative positions that participation in the policy 
formulation process is illegitimate or inefficient. Their concern for rapid development and the central role of the public sector in achieving economic and social goals may lead them to give policy making responsibility to elite planning bodies in the national capital. These elite planning bodies may then be protected from the pressures (pettiness or selfishness) exerted by interest and clientle groups, and from the delays and conflich resulting from open debate, inputs for legislative bodies, and exposure to mass media.

The policies of a regime have great impact on the daily lives of citizens in nearly every Third World country. Many Third World countries have extensive and active public sectors involved in many aspects of economic and social life. State bureacracies may be among the strongest institutions in the society. Many of the most important policies established by political elites include agrarian reform, urban development, housing, social security, health, employment and education. Each of these policies are of concern to virtually all citizens. Furthermore, in a context of very scarce resources, who gets what and how much is likely to be of central concern to the populace. Government plans where to locate industries, who should receive government contracts, or who should be included in preventative health programs will likely ignite the potential for conflict and the desire to influence such decisions. Thus, while participation is frequently limited to policy making, there still exists a great desire among citizens to affect the outcome of government decision making because such outcomes affect them all down to a personal level.

Many Third World countries have found the implementatin phase of the policy process to be particularly suited to their needs. In attempts to obtain government goods and services, individuals and groups find it worthwhile to focus their demand making efforts on officials and agencies empowered to distribute benefits, or on politicians who may have influence 
on individual allocation. Patron factions, client linkages, ethnic ties, and personal coalitions that are often the basis of political activity are well suited to making individualized demands on the bureaucratic systems for the allocation of goods and services (Heeger 1973).

The implementation process may be the major way in which individuals and groups are able to pursue conflicting interests and compete for access to scarce resources. It may even be the principle of the interaction between the government and its citizens, between public officials and their constituents. More over, the outcome of this competition and interaction can determine both the content and the impact of programs established by government elites, and thus influence the course of a country's development. With the concentration of political activity on the implementation process, it is likely that policies and programs will be more difficult to manage and predict, and even more subject to changes or alteration in the Third World countries than elsewhere.

Implementation of public policies in the Third World countries is the focus of the case studies in this text. Specifically, land settlement programs intended to benefit certain groups of peoples in the societies studied. The intended beneficiaries include primarily the rural poor and landless peoples. The overwhelming characteristic of Third World countries are the large proportions of their populations that live below, at, or slightly above subsistence level. These portions of the populations are in dire need of the goods and services provided by government programs. Yet, most Third World governments are authoritarian and too busy seeking solutions to problems of political participation and conflicts to be deeply involved in providing the basic needs for its citizens. This suggests that the capacity of poor populations to acquire benefits from their government may be strictly 
limited in an environment that minimizes the influence of numbers on political decision making through the elimination of open elections and rotation of political leadership.

Most of the case studies in this text illuminate the general methods of implementation and the political activity associated with it. Most of the Third World countries exhibit implementation of policies that are distributive or redistributive, including public land for the landless, rural development, and increase in agricultural production. The implementation of policies is done through governments which determine how scarce resources will be allocated and who should be the beneficiaries. Beneficiaries of policy implementation, generally low income and low status groups, are presented in these case studies as powerless people who strive to elicit resources and responses from their government in the face of considerable opposition from those who are threatened by them.

The literature of land settlement policy implementation provides a framework to help analyze the many variables which interfere with implementation. The variables identified in the case studies of Third World countries presented in this text. These variables are components of the content and context of the the policy environment. The variable include national level planners; national, regional, and local politicians; economic elites; recipient groups; and bureaucratic implementors and resources.

Land settlement has been initiated to solve some of the problems confronting Third World countries, including the need to increase agricultural production, correct spatial imbalance, and difuse serious political problems resulting from the existing agrarian structure. The major focus of this study on the resettlement schemes is from the point of view of the populations concerned in relation to the objectives of the policy 
implementation. This study reports the findings from examination of land settlement programs in Iraq, Indonesia, Malaysia, the Philippines, Somalia, Ethiopia, the United Republic of Tanzania, and Israel.

These studies present the similarities and differences in the policies of land settlement programs. This examination of land settlement policies is an attempt to identify the problems facing such projects and to learn what should be done to improve the settlement programs.

There are three sections in Chapter XII which provide discussion. First, the performance of settlement projects, concentrating on the extent to which they achieved their objectives. Second, the major economic and social problems confronting settlement programs. Third, whether resettlements are an appropriate policy response to population redistribution. Chapter XIII presents discussion examining the factors affecting success or failure of land settlement policies. 


\section{CHAPTER III}

\section{INTRODUCTION TO CASE STUDIES}

The importance of developing national resettlement programs in Third World nations have often been couched in their potential for providing tidy solutions to numerous problems. Problems faced by these nations have included the need to increase agricultural production, correct spatial imbalances in population distribution, exploit frontier land for reasons of national security. Third World nations have also cited the need to diffuse potentially serious problems resulting from existing agrarian structures, poverty, and increasing landlessness and unemployment (Oberai 1988).

Pressing land tenure problems in the arid areas of Iraq were the impetus for the development of land settlement projects following World War II. A resettlement project known as the Dujaila pilot plan, the first of its kind in Iraq following World War II, was implemented to address problems of land tenure.

The idea of trying to alleviate population pressure and poverty in Java, Indonesia by organizing and encouraging the movement of people to the outer islands of Indonesia is one example of a resettlement program. During the 1970s, fueled by the oil boom, Indonesia's transmigration program became one of the largest voluntary land settlement programs in the world (Arndt and Sundrum 1977, Arndt 1981, Hull 1981).

The objective of Indonesia's population transfer was economically based 
rather than for the the relief of population pressure. The lack of infrastructural facilities, such as housing, drinking water, roads and irrigation was the primary factor in settler's decisions to abandon the land settlement scheme.

Malaysia, a relative newcomer to implementing land settlement schemes, developed a style of implementation that received worldwide attention due to its performance. The emergence of resettlement programs among other southeast Asian nations can be traced back to the turn of the 20th century. Though the Malaysian programs did not begin until the mid 1950s, in less than a span of 30 years large tracts of land have been developed and occupied by previously poor and landless peasants (Bahrin 1968, 1977).

In Malaysia, population redistribution in and of itself was never an objective of land settlement and development. In part, it was seen as a means for promoting regional development. The principal objective was to develop land for the landless and unemployed people.

Among the various objectives of the Philippine government were the use of resettlement programs to improve the quality of life among the poor, increase agricultural production, and accelerate national and regional development through exploration and colonization of the frontier. This involved the distribution of publicly owned agricultural land to landless families. Resettlement has also been used by the government to encourage migration to sparsely populated regions of the hinterlands for the purpose of developing new communities that would serve to fulfill desired objectives (Din 1981). The program in the Philippines was driven in part by a 1971 report prepared by a consultant for the Harvard Advisory Group which advocated the abrogation of the land grant system and proposed a comprehensive planned utilization of government lands through an 
appropriate settlement policy. Support of individual initiative and low cost settlement programs were key elements of the Philippine resettlement policy and were attributable to the report (Pascual 1966, Simkins 1968, World Bank 1973).

The policy of resettling Somalia's nomadic population predated the 1974 drought. However, the international aid extended to Somalia in response to the drought brought its policy into greater focus and added momentum to its implementation. The major objective of the resettlement policy as it evolved since 1974 was to attain a major redistribution of Somalia's population so as to reduce the ecological deterioration of the rangelands and to redirect urban growth into productive rural enterprises. By developing large-scale irrigation schemes and coastal and deep-sea fishing, the Somalia government hoped to diversify the national economy in order to achieve greater national selfsufficiency and reduce the country's increasing trade deficit. Secondary, but not less important, were the goals of population redistribution (Cassanelli 1975), provision of social services to Somalia tribes, and accommodate war refugees (Scuddert 1981, Afzal 1983).

The settlements of Somalia were successful in creating social infrastructures for many families, but income and production potential were not met. Education and health care at the settlements were well above the national average. Increases in elementary school involvement were noted.

From 1961 to 1966 the United Republic of Tanzania adopted land settlements as part of their national planning strategy for socioeconomic development. The objectives were increased agricultural production, and population redistribution from heavily populated areas to areas of low population densities. Other objectives included provision of essential social services such as health care, education and clean water (Maro 1982, 1983). 
The United Republic of Tanzania sought a complete transformation of rural society to improve the overall social and economic well-being of the nation through the villagization program. The villagization program was an attempt by the government to evolve a coherent rural development strategy with the aim of communal production and to engage in the collectivization of rural development. Despite the villagization project, levels of agricultural production were low and rural income remained inadequate.

Ethiopia, one of the largest nations in Africa with a population of nearly 35 million during the 1970s, experienced problems with settlements. There was a great potential for developing land and moving people from high density areas to low density areas. The major objective was to settle about 500,000 people after the 1974 drought. The settlements proved not to be wellbalanced. Most settlers concentrated in large numbers in the highlands. The land became fragmented, creating great pressures which led to low agricultural productivity and landlessness (Kassaye 1978).

Israel was considered a pioneer state with extensive experience in land settlement planning and implementation. Israel's objectives were guided by the priority to utilize uncultivated land as part of rural development.

The intended policies of resettlement programs throughout Third World nations have differed to varying degrees, but some commonalties have emerged. Most often, the clear of objective of relocating people was initially met. Yet whether the relocated population remained and prospersed depended in large degree to the strategies for implementation. 


\section{CHAPTER IV}

\section{DUJAILA LAND SETTLEMENT IN IRAQ}

Dujaila was a pilot land settlement project. Begun in 1945 it was the first project of its kind in an Arab Middle Eastern country (in the Arabian Peninsula) and the forerunner of a large scale social experiment. It was significant in that it was all Iraqi-conceived and executed. The first Iraqi projects attempted to solve the pressing land tenure problems of the arid area of Iraq. The thought was if the coming years proved as successful for Dujaila as the preceding six years, this pilot project would pave the way for five more larger projects of a similar type planned in Bagdad. Other Middle Eastern governments were watching the development closely. Their agrarian problems were not totally dissimilar, and they hoped to learn much from the work of this project.

The project was conceived before the Second World War, but was not initiated before completion of the barrage on the Tigris River at Kut (Fig. 1). The barrage could raise summer water levels in the river by almost 14 feet. It functioned to draw water over the southern banks of the Tigris by gravity. The barrage was completed in 1939. War prevented action on the Dujaila project until 1945. Since its inception in 1945, the project, with its initial one hundred settler families, grew quickly under definite rules (Fisk 1951)

Each applicant was given a 100-meshara plot (each meshara $=2500$ square meters). The settlers were required to be farmers and landless, at least 18 years 


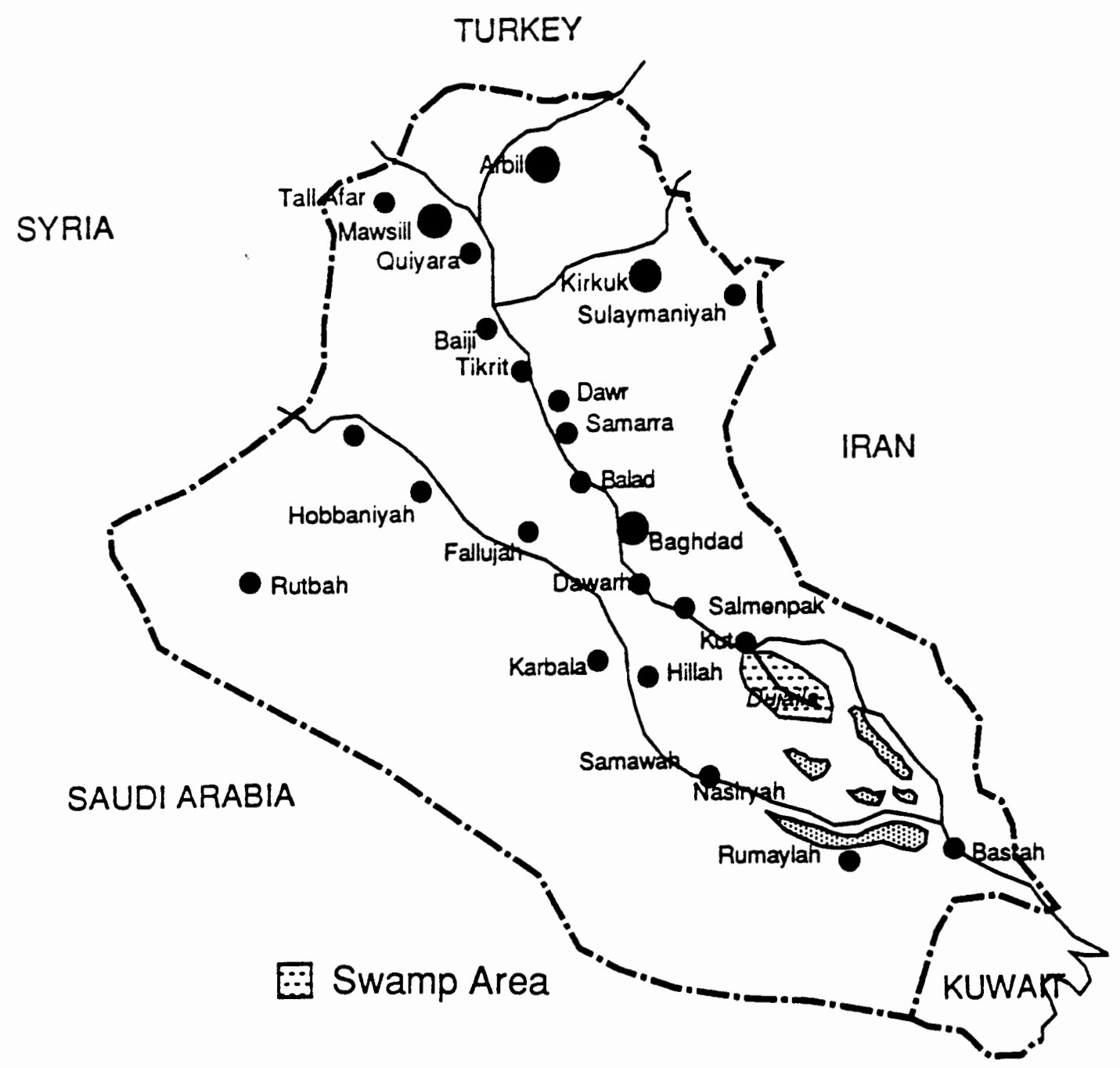

Figure 1. Location of Dujaila land settlement. About 100 miles southeast of Bagdad (Fisk 1951). 
old yet under 50 years old, with no criminal record. Each settler was required to live with their family on the land they tilled and worked. Preferably, the settlers were residents of one of the two southeastern provinces of Iraq, formerly known as Kut and Ammra, now called Messan. Where the Dujaila projects were located with this stipulation, the government avoided mixing people from different tribal backgrounds. Alternatively, great care was taken to settle people of different local tribes adjacent to each other to promote amalgamation and long-range harmony between the settlers.

In 1945 the government established the Dujaila Project Board, which required that settlers abide by the instructions given to them. In this way, the government through the Board was able to introduce techniques and crops that the settlers were not previously acquainted with. Each settler signed the development and cultivation contract created by the Project Board which included information about crop rotation, planting fruit trees and vegetable gardens, cleaning and digging of feeder canals, and housing style and construction. Each settler family was granted 100 Iraqi dinars $^{1}$ as an establishment loan, repayable in five years. Settlers were not allowed to sell, lease or rent their land for a 10-year period. During this time the settlers' only source of credit was the Agricultural Bank of Iraq. Any settler who disobeyed these instructions after three warnings from the project authorities could be ousted and the land opened for resettlement (Al-Haidari 1950).

In return, those who abided by these regulations were granted a 100donnom area plot of land, a free water supply, and the establishment loan. They were encouraged to make full use of the cooperative associations, demonstration farms, educational programs, and technical advice available on the project. After 10 years settlers received their land and all rights as a gift

1 An Iraqi dinar was equal to 4 U.S. dollars at that time. 
from the government. In case of a settler's death, the land passed to his heirs under identical contractual requirements.

These regulations were a spirited effort to develop small independent settlements comprised of responsible landowning people. It was hoped that their improved living standards would set an example and influence labor conditions on adjacent, privately owned land. It was thought that the change in labor conditions would encourage other farmers to desire independence from communities.

\section{PROJECT DESCRIPTION}

\section{The Dujaila Land}

Flat subtropical desert land lying east of the Mesopotamian market center of Kut City (Fig. 2) was the site of the Dujaila project. The Dujaila project was comprised of 125,000 donnem which had been allocated by the Iraqi government. The land was divided equally between a few wealthy landowners and the Iraqi government. As the Dujaila project was too new to have had any substantial influence upon the privately held lands, except as beneficiaries of the project's water and machinery availability discussion of these lands will not follow.

The land used by the settlers in the project for agricultural purposes was an area that could be covered by gravity pump from the Dujaila Canal and its 12 distributor channels, a total area of 110,000 donnem. Nearly all of this land was potentially productive desert land at the beginning of the project. Eighty thousand $(80,000)$ donnem could be irrigated by pump, and of this land, $20 \%$ was too sandy for use. Administration, utilities, schools, roads and experimental farms occupied a minimal area. 
$\square$ Land Subject to Temporary Flooding

Unoccupied Flow Irrigated Land

Occupied Flow Irrigated Land

$\because$ Dujaila Project Boundary

EPrivately Owned Land

Adminstrative Land

- Dujaila Distributary Canal

图Salted Land

-7 Dujaila Canal

- GDujaila Water Flow Limit

High Land
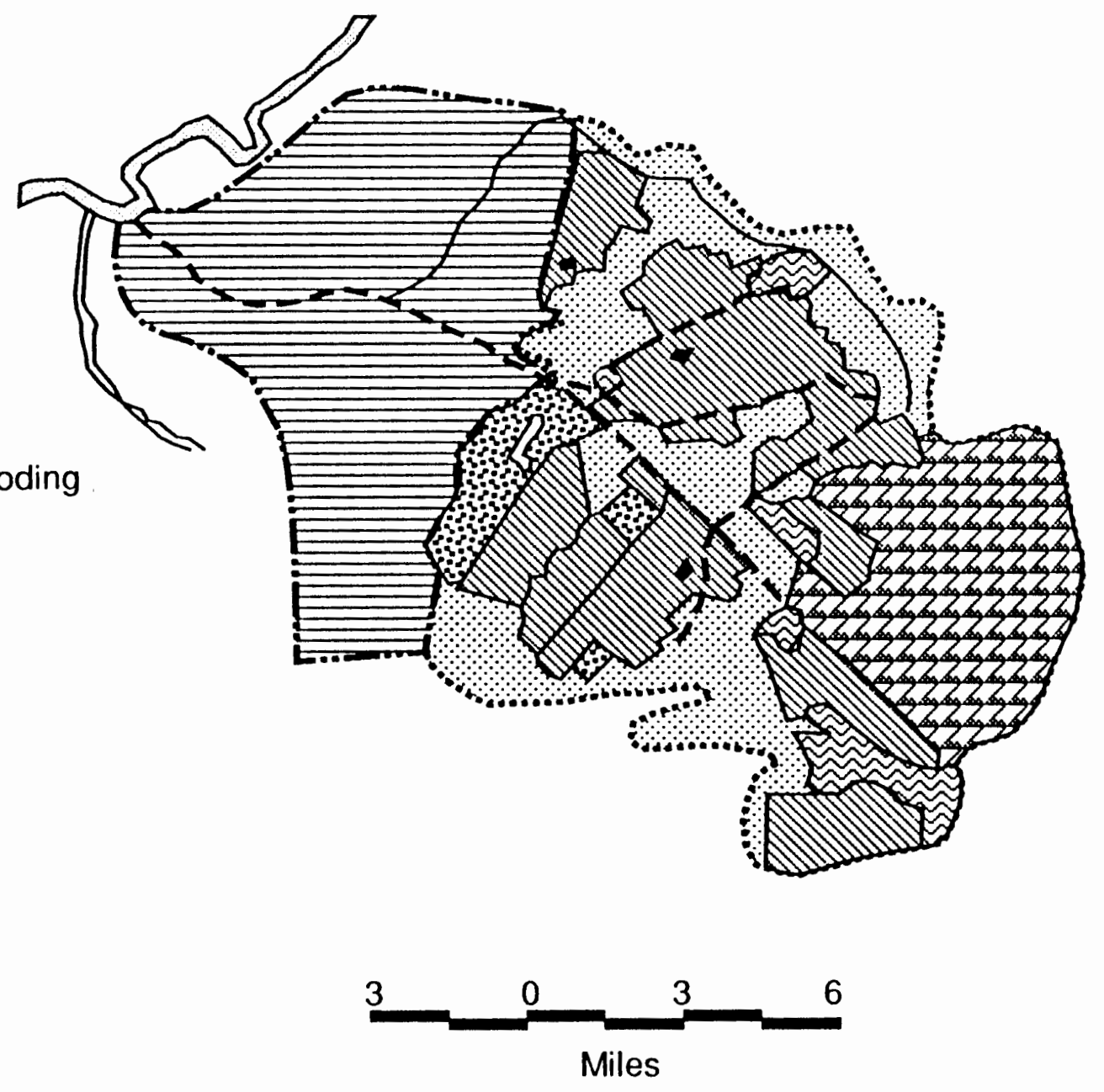

Figure 2. Plan of Dujaila land settlement (Fisk 1951). 
Water Policy of the Project

Dujaila water was distributed to state land only, except in specific instances where the government Council of Ministers allowed private landowners specified quantities. In return for this water, landowners (called Shayhk) determined whether to distribute one-fourth of their land to the farmers or pay a pro rata share (1.25) of Iraqi dinar per donnem of the expenditures incurred in constructing the canal system. Water distribution was accomplished through the Dujaila canal, leaving the right bank of the Tigris River 300 meters (about 1050 feet) upstream from the Kut City barrage. The canal control by headgates was designed to pass 28 cubic meters per second, which is enough water to supply both flow irrigation and the slightly higher irrigation lands. The canal, while designed to carry enough water for both kinds of irrigation, was excavated to a three-meter depth, allowing but 18.5 cuses (unit equal to one cubic foot per second) discharge. This was the full cultivation water required for flow irrigation. When money was made available for pumps, the canal and its seven distributary branches inside project land were enlarged to full capacity. The distributaries, of unequal size due to variations in the water of each area, were designed to a slope of 10 centimeters per kilometer, while the average slope of the Dujaila itself was 7 centimeters per kilometer throughout its 51 kilometer length. Modern steel headgates were used to regulate the flow of water from the main canal into its several distributaries and from these to the feeder channels irrigating individual farms.

\section{The Administration and Facilities}

Project lands were divided into many sections and segregated according to the distributary canal servicing each particular section. The original settlers 
were located on Sections Seven and Eight, which were nearest to Kut City. Subsequent settlers were located on land at a greater distance along the canal. The administrative services were an integral part of the project. Experimental farms, scattered in several of the project's sections, were one of the two means by which the government disseminated its advice and concepts of modern farming. The farms, of the same size as the settlers' 100 donnom plots, made use only of tools available to the settlers themselves and produced those crops which the government required each settler to grow. By practicing advanced cultivation techniques and producing heavier crop yields, often with fewer man-hours of labor, the experimental farms successfully convinced cultivators of the value of their techniques.

The experimental farms would have been more effective if limited to the single function of education via demonstration. As it was, they were under-staffed even for that function and had to also serve as horticultural advisor for planting trees and vines and as seed nurseries for the entire Dujaila project. There were not as many experimental farms as there were sections within the project. Because of the distance involved, the settlers' visits to these farm sites are sharply curtailed, greatly reducing their effect. In addition to the experimental farm plots, skilled agriculturalists living in the project offered demonstration lectures on specific local farming problems. Often these lectures were supplemented by machinery demonstrations. It was hoped that future growth of these educational efforts would include the introduction of visual aid techniques, particularly since many of the settlers had never seen such demonstrations.

Local administration was carried out by a small government staff stationed in the project. The staff was charged with enforcing the law and rules of the Dujaila project and with supplementing the activity of the 
resident technicians. Provisions for health and education, both adult and primary, were inadequate beyond the section center.

The consumer and farm cooperatives were the most important services rendered to the farmers in Dujaila. The cooperatives were conducted entirely by the indigenous agricultural population. For a yearly subscription of one Iraqi dinar, each farm family could take advantage of the consumer cooperative's services, purchasing personal and household goods at well below the prevailing market price. The consumer cooperative, in common with the farmer supply cooperative, maintained a retail outlet in the administrative center located in each section. Membership in both forms of the cooperative was open to officially recognized Dujaila settlers only, because of the minimal cost of and the benefits offered by these cooperatives (Fisk 1951).

The Farm Supply Cooperative was very important as it furnished needed farm machinery and seeds to small landholders. Tractors, with their supplementary equipment, including driver and petrol, were available for the nominal price of 300 Iraqi fils (about $\$ 0.70$ at that time) per donnom. Tractors and maintenance stations manned by full-time specialists, were located in the fully settled sections of the project. Unfortunately, mechanical equipment was in short supply, opening the way for petty abuse, which was encouraged by the fact that the cooperative could rent the same equipment for the profitable rate of 600 fils per donnom to the neighboring landlord owning land in the privately held land watered by the Dujaila Canal. Most cultivators signed up for equipment as much as three to six months prior to their actual need for it, to insure their obtaining its use. The Farm Supply Cooperative, which was a voluntary organization, charged members two Iraqi dinar per year for the privilege of using its facilities, although new settlers are allowed 
lenient terms their first few years. This sum plus governmental assistance supported the nonprofit operation of the organization as a cooperative society.

The cooperatives were the government's agents for increasing both the quality and quantity of crop output. As this depended upon the use of improved varieties of seed, specialized cotton and cereal seeds were available through the cooperatives at attractively low prices. The availability of low cost seed to settlers benefitted the government's goals of increasing crop quality and quantity.

The good success of the cooperatives turned the Project Board's attention toward a marketing cooperative. It was hoped that this activity would be functioning before the 1952 harvest season. Farmers, for many years accustomed to selling their crops to town grain merchants far in advance of the harvest, had been unable to change their ways. As a result, they lost $50 \%$ or more of the final market value of their harvested crops. Local grain merchants and landlords, feeling threatened, objected strongly to the plan for a marketing cooperative. Only the insistence of the Dujaila Project Board put the marketing cooperative plan into the starting stage. Unfortunately, landowners possessed disproportionate political strength. Marketing cooperatives presented an immediate threat to their way of earning extra wealth and such plans were vigorously opposed.

One satisfying introduction by the administration were the tree plantings along the public roads uniting several sections and their administrative center. Many different trees were planted such as eucalyptus, poplar, mulberry and tamarisk, all quick-growing varieties that thrive under irrigation. They were interspersed with sisbania and casuarina bushes, acting to disrupt the monotonous flatness of the southern Mesopotamian plain. 
This vegetation sheltered settlers from awesome dust storms and provided nice shade in the summer.

\section{Dujaila Project Population and Social Life}

Estimates indicate that between 1000 and 1200 families were in residence as of June 1951. The population was estimated at about 15,000 people. Each family averaged between five and seven persons. In addition, approximately the same number of hired laborers and their families were supposed to be living on project land. The landowner was free to employ one man and his family, from any place he chose. The settler himself however had to meet the qualifications according to the Project regulations. When sufficient applications had been received by the Project board, actual settlers were chosen from among qualified applicants by lottery. By 1951, farmers wishing land in Dujaila had to show that they had completed both their primary education and military service (Al-Haidari 1950).

Additional labor was needed in the Project only at harvest time. Then local shepherds were employed for a few weeks to harvest and thresh grain. In return for their labor, they were paid both in cash and kind, receiving board and a space in the grain fields to pitch their tents. They were allowed to graze their animals on the stubble for a limited post-harvest period. This was in late May and June.

\section{Dujaila's Homestead}

The Dujaila homesteads, shown in Figure 3, were laid out in square shapes or rectangular patterns aligned to conform to a grid pattern of irrigation canals. Each group of four formed a small settlement of 4 to 12 buildings containing between 40 and 50 people. The law requiring 


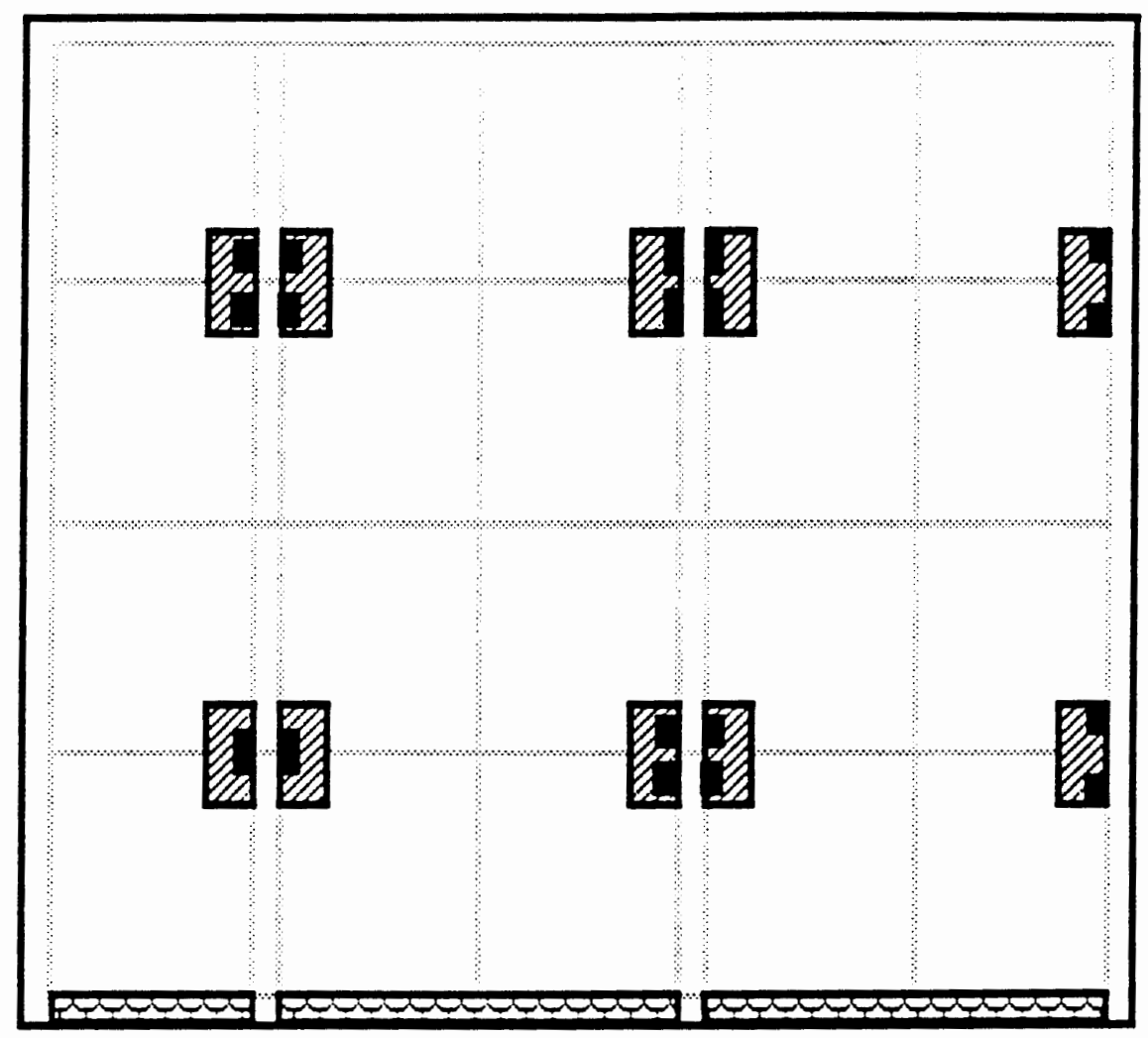

$\stackrel{5}{=}$ Distributary Canal

Garden and Pasture

Ex죠 Feeder Canal

Building area

Figure 3. Dujaila settlement pattern (Fisk 1951). 
settlers actually to dwell on their own land was intended to insure that the cultivator and owner were the same person. This dispersed settlement pattern in Iraq was also intended to reduce public security requirements. Some incidence of crime was reduced successfully within the Dujaila Project. The settlement pattern requirement worked great hardship upon the settlers, although it eliminated travel time from village to farm. Accustomed to dwelling in villages, the sociable tribal people resented being relegated to such minute settlements. The great distance,often exceeding 10 kilometers between farm houses and administrative centers of individual sections contributed to diminished attendance at demonstrative lectures and schools. Frequent exchange of individual farm experiences was also curtailed, a very serious fault among an illiterate population.

This settlement scheme had a twofold effect on water use. The provision of pure, piped water over great distances for individual household use proved cost prohibitive. Furthermore, diversion of water for household use reduced its availability for the all-purpose irrigation ditches. Individual wells may have solved the drinking water problem if small pumps were installed at each of the four corners of the settlements. The social services problem was more fundamental. Small settlements in hexagonal patterns, with farms surrounding each village at distances no greater than 4 kilometers relative to surrounding villages may have provided an answer for future settlement projects under consideration in Bagdad at the time.

\section{$\underline{\text { Soils }}$}

The soil's rich loam, with occasional sandy patches, constituted the thin topsoil layer. Because of the high salt content of the surface layer, shallowrooted cereal and cotton crops could not be expected to produce as abundantly 
as was possible on the well-drained lands found in the north of the country. Alternatively, the loamy subsoil had a below-average salt content. This favored immediate results when the soil was washed, thereby lessening the pernicious influence of topsoil salts. Unfortunately, the loam had a poor structure, tending in places to cake thickly enough to prevent seedlings from pushing through the dried-out surface. This condition prompted the introduction of long-rooted leguminous crops, like alfalfa and clover, to improve the soil structure. In addition, these crops supplied needed humic content (Powers 1954, Buringh 1955).

Such crops as Berseem were excellent winter crops, while alfalfa provided good summer forage. Both crops increased the production of animal protein and products by supplying a reliable fodder crop. The introduction of such crops also gave the settler a better understanding of new fixed location agriculture as contrasted with the extensive, shifting irrigation cultivation practiced over most of the country. Alternation in salt and nutrient content, as well as changes in soil structure, were responsible for the variations in crop quality and density readily observable in the fields (Lebon 1964).

By the sixth year of the project salt was not a problem. However, the lowest lands were removed from cultivation and the settlers occupying these salted plots were relocated. The key issue in the Project was that drainage was not provided for in the original plans of the Dujaila land as a whole. This is why older portions of the settlement salted up beyond reclamation (Simmons 1965). Temporary local drains could have been constructed to lead excess water off to the lowlands east of the canal, where the waters would have been disposed of through evaporation. If such a project was to be permanent and free from malarial swamps, large drains would have to have been dug back to 
the Tigris from the projects. Pumps could have been employed to lift the water back into the river again. The area of land at the eastern end of Dujaila was fertile, and could be commanded in its entirety by flow irrigation. But it was subject to temporary coverage by water during high floods and therefore susceptible to malaria breeding.

Soil erosion was a minor but neglected factor within the Project. Erosion control included only the banks of the main canal and its distributaries. The richness of the desert's extremely fertile loam, deposited mainly by the Tigris' accumulation of fertile alluvium was substantial, yet the rich soil was not necessary except for certain field crops such as cotton. Animal manure was either collected for fuel or sometimes scattered upon the vegetable or fruit trees. Some manure was left to enrich the area left for pastures attached to each farm of the settlement.

\section{Crop Rotation Practice}

The rotation of crops was not new to the Iraqi farmer, but it was a very important factor for permanent farmers. The practice had been used by leaving a field fallow. That meant one year a farm was left without cultivation until the following year. But the system adopted for the Dujaila settlement was more in line with the extensive, shifting agriculture practiced on private lands near Dujaila. For example, the grain crops, such as wheat and barley, were on the same plot of land as shown in Figure 4. A threedonnom area of cotton was located in different fields with each passing summer, thereby taking advantage of the scattered patches of good soil on each farm. The vegetable patch remained close to the farm bulking to make it easier for car access and fertilizing with animal manure. The fruit trees remained fixed, and the pasture area was required by law to remain 


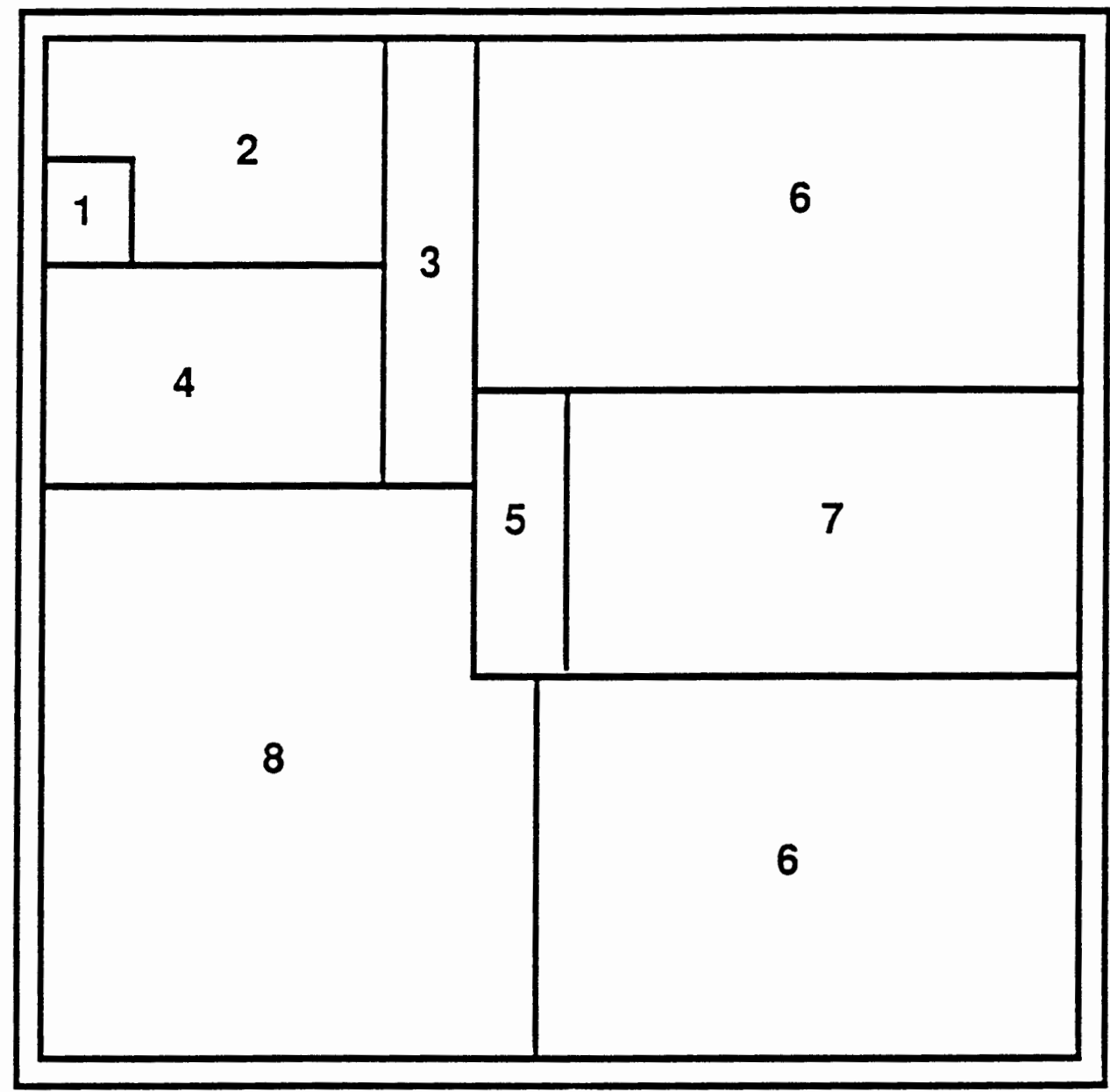

1. Building 2. Vegetable 3. Pasture 4. Fruit Garden

5. Cotton 6. Fallow 7. Barley 8. Wheat

Figure 4. Typical land use on a Dujaila farm (Fisk 1951). 
near the farm buildings. The most appropriate rotation may have been a three-year rotation of cotton, berseem clover, and wheat and barley. Such a system would have involved two winter crops and one summer crop on each field. One winter and two periods of summer fallow within each rotation cycle could yield greater crop production from the same land area. A threedonnum plot of alfalfa could be rotated about the poorer soil patches once in each cycle, improving structure and organic content and providing additional fodder for the settler's animals.

The crops used in the settlement farm were typical of Iraqi agricultural field crops. Wheat and barley were the dominant cash crops and occupied most cultivated land in north and south Mesopotamia including the Dujaila Project. Wheat was used for bread and barley was used for bread and exported for beer production. Both crops were grown in shallow basins that were flooded three to four times a month during winter. The actual watering interval depended upon temperatures and evaporation rate. The common harvesting method was by hand sickle, and grains were loosened in the husks by animal's hooves. Wind winnowing then completed the threshing process. Sometimes threshing was done by wooden sledge, with has rotating steel blades and a roller, to give shorter lengths of straw used for winter feeding of the animals and for mud bricks for home construction. The extra cereals produced for sale are marketed by the individual farmer in an unprofitable old manner, in which the town middleman absorbed the bulk of profit. But in the later years of the project, the cooperative marketing was very helpful to remedy the situation.

Grains were grown as winter cereals, keeping the farmer busy plowing and sowing in the fall, watering in the winter and harvesting in the spring. Cotton, a summer crop, was grown on a small area to give the farmer a year- 
round farming income, albeit small. Crops, such as corn, sorghums, mung beans, millet, sesame, and other vegetables were raised on a small scale as a summer crop.

The tree orchard was introduced to the Dujaila settlement as an integral part of the Project's crop and diet diversification. Diversification was central the Project's goal of increasing the self-sufficiency of individual farms and teaching farmers the desired potential of their new life. As shown in Figure 5, some gardens planted in 1946 yielded excellent crops of grapes; and the greenery around these established farms formed a refreshing contrast to the dull mud villages of the large estates adjacent to the Dujaila Project. The produce from these gardens were only for home consumption, because the area devoted to each variety of fruit was too small to encourage sale. Rapidly growing mulberry and eucalyptus trees and the casuarina and sisbania bushes acted as partial windbreaks around the houses. They also provided cooking fuel for the individual household.

The vegetable garden, like the orchard, was cultivated under open border and trench irrigation, receiving water once every three to four days. From this five-donnom plot each family was expected to supply its own needs for vegetables. At the inception of the Project growing vegetables was considered an inferior occupation, so farmers needed to be educated on how to tend their vegetable plots until they had seen the advantage of growing and consuming their own vegetables. As a result of the wide variety of food freely available to each household from their gardens it was hoped that the general health would be raised well above those farmers laboring nearby on the landlord plantations. 


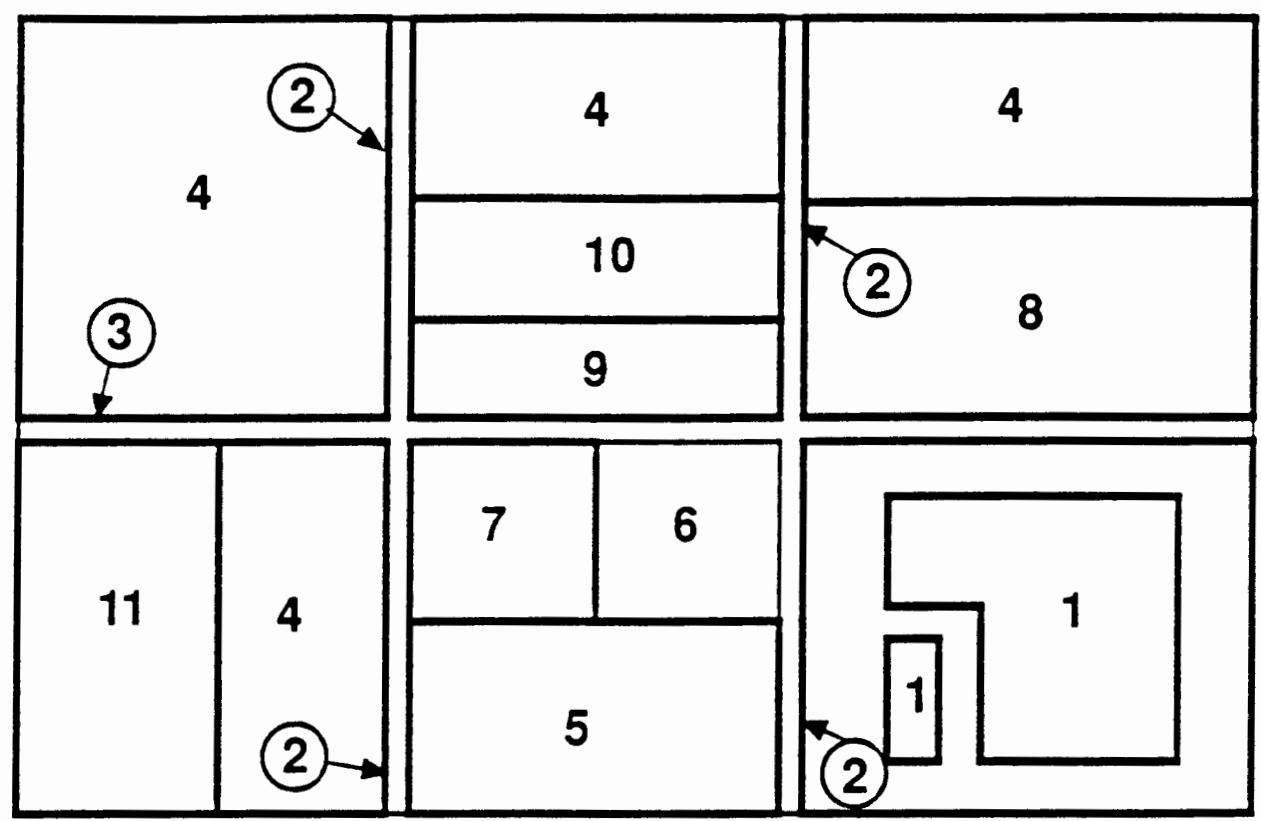

1. Building ; 2. Fig Tree ; 3. Mulberry Trees ; 4. Date Palms ;

5. Pomegranates ; Plum Trees ; 7. Greengage Plums ; 8. Vines

9. Crabapples ; 10. Apricot Trees ; 11. Apple Trees

Figure 5. Fruit garden layout on Dujaila farm (Fisk 1951). 
Livestock in Dujaila

The goal of agricultural diversification in the Dujaila Project led to the introduction of livestock such as cows for milk, and poultry and ducks for eggs and meat. Donkeys normally were kept in each farm for transportation. Some farms had about 30 head of sheep for wool and lambs, with a few goats for milk. The animals grazing the grain stubble helped the settlers to support more animals than would otherwise be possible. Diversified agricultural production made it essential for the settler, in order to profit, to add leguminous crops which helped the soil's fertility.

\section{Settler Adjustment}

The settlers' adjustment was very slow in the beginning because nearly all of them were not familiar with the new environment or many of the crops. However, by 1951 the settlers had realized the value of such crops. They had become free of the debt they used to have under their landlord. Most of them possessed cash incomes, and they had good diets. Freedom replaced the feudal system, and enhanced health increased their ability to enjoy new status and well-being. With good housing, with greenery around such houses, better clothing and some home furnishings, they became more active and interested in their lives. Some of them considered themselves prosperous enough to have extra wives. In general, the settlers of the Dujaila Project became ambassadors promoting such settlements in other parts of Iraq.*

\footnotetext{
*As county agent at this time, the author was informed of the preceding by Hasan Mohammud Ali, director of Dujaila project, and Fuad Izzet, first technical secretary of the Department of Agriculture, Iraq.
} 
Did the settlers adjust to the new way of life? The adjustments were very slow in the beginning, because they were not familiar with the environment. Nor were they familiar with cash crops and the time required to produce them. But when their diet and their health improved, they recognized the value, and they were more than ready to accept their new ways. Financially they were better off than before. They were free of debt and possessed some cash incomes. They enjoyed the freedom to be their own bosses and the ability to enjoy their new status. Especially with good housing, often with attractive greenery around their houses, with better clothing and some home furnishings they became more interested in life beyond the limits of their farms. Dujaila settlers considered themselves prosperous people. The Dujaila Project yielded practical experience for the Iraqi government. Certain points had been clarified during the first six years, which pointed out what must be done to improve the Project and extend the Dujaila idea to other parts of Iraqi. Social, health and education services were in the first stage of development and inadequate. Recreational facilities were totally lacking. There were no medical services on the Project.

I've primarily discussed the successes of the Dujaila project during its first six years of existence. The problems the pilot project faced included an inadequate drainage system and consequent diminishment of crop production. The drainage system failed to prevent the toxic build-up of salt. Crop failure due to increased salt content discouraged settlers and left them frustrated with their efforts (Fisk 1951). By the end of the six year period examined many settlers had abandoned their plots and moved elsewhere, leaving the whole project in a state similar to a salt mine (Phillips 1959). 


\section{CHAPTER V}

\section{LAND SETTLEMENTS IN THE REPUBLIC OF TANZANIA}

Tanzania, similar to many countries in Africa, has adopted land settlement policies as part of their national planning scheme. The primary objectives were increased agricultural production and improved socioeconomic development. A secondary objective was population redistribution via relocation of landless and displaced peoples from heavily populated areas to areas of low population density.

From 1961-1966, the Tanzania government tried to transform agriculture through capital-intensive settlements; these were limited and affected only 100,000 people. But in 1967, the government proclaimed the Arush Declaration. In the spirit of the philosophy of socialism, the Declaration set the stage for collectivization of the entire rural population into nucleated settlements called Ujamaa villages. The Arush Declaration and its precepts were viewed as a precondition for rural development. Both the policy and the strategies of implementation visualized a future society based on nucleated settlements in which land and labor were mobilized for cooperative and communal production. Equitable income distribution would be encouraged through such a settlement pattern as would cheaper and cheaper provision of social services. The land settlement and population redistribution in Tanzania had two eras (Boesen 1979, Hyden 1980). 
Tanzania had some experience with land settlement during British Colonial rule. Such rule was used during 1930-1940 to concentrate peasants into compact settlements. This was one of the colonial system's methods to increase the agricultural production. In the 1950's, the colonial government encouraged cash crop agricultural settlements.

The objective of colonial agricultural policy was to increase production, especially of cash crops. Such policies were improvements in traditional agricultural practices in soil conservation, terracing and land use planning. There was no emphasis on the introduction of new methods, new techniques or innovation, nor any concern for welfare of the peasant producers or the provision of social services. The consequence of such colonial agricultural policies was anticolonial resistance on the part of the peasants, which finally mobilized into a mass nationalist movement demanding self-rule government.

\section{POST-COLONIAL SETTLEMENT}

In 1962 the independent United Republic of Tanzania had been advised by the World Bank to establish land settlements on vacant land by removing people from crowded or high-density areas to new land. The World Bank suggested movement of people to new land would encourage them to be more open to change and adoption of new ways of agriculture. The government estabtishted the Village Settlement Agency to supervise and advise settlers and government agents regarding implementation. According agency directives, pilot planned settlements were established in various parts 
of the country as centers of modern farming. They numbered 20, with populations of 20,000 people. Each settlement was to have 250 families, with managers and other experts in agriculture. All machinery used in the settlements was paid for by the government.

Unfortunately, five years after their inception, most of the pilot settlements were abandoned, but some were converted to Ujamaa villages. By 1966 the Village Settlement Agency had been dissolved. The transformation of agriculture through the settlements had failed for three reasons. First, overcapitalization: in many of the schemes, there was more machinery than necessary in relation to land and labor. Consequently, both labor and equipment were underutilized. Second, production was low and scattered in many farms that could not be easily supervised. Third, the settlements were managed by inexperienced officials, with no settler participation in management (Dumon 1969).

\section{SPONTANEOUS SETTLEMENTS}

In addition to the many government-supervised settlements, there were many voluntary settlements that were on a cooperative basis and received some assistance from the government. Some of these settlements were motivated by an urban youth organization named Tanu Youth League (TYL). Settlements established by TYL were self-reliance and exhibited a good quality of life. The Tanu Youth League had been established to recruit youth from all over the country. They established more than 500 small settlements. Such settlements were less capital-intensive and involved politically dedicated young people who devoted their time to productive efforts in their settlements. The causes of the eventual failure of many TYL settlements, 
however, were mismanagement and misuse of funds (Dumont, 1969).

In 1963, a successful spontaneous settlement was established by the Ruvuma Development Association. About 400 families from very poor areas scattered across the country moved into 17 new settlements. The guiding principles were communal farming and self-reliance. Each settlement elected its own manager and a management committee from among themselves. They cultivated a wide range of crops, raised cattle and established weaving and spinning, brick making, flour milling and timber production, and reinvested their savings in social services and transportation. After 1968, the Ruvuma Development Association was banned, allegedly for representing the elite (Dumont, 1969).

There were two lessons learned by the government through their settlement experience. First, they accepted that nucleated settlement and broad extension of social services were the prerequisites for rural development and for checking the rural-urban drift of youths. This idea led to the formulation of the Ujamaa policy, which referred to living and working together in communities for the good of all. The second lesson was that capital was scarce and could not therefore form the basis for rural development; rather land and labor should be mobilized as the basis for socioeconomic development. The failure of the post-independence land settlements set the stage for nationwide planned settlements with wider objectives that encompassed more than increasing the production of cash crops (Maro, 1983).

What is ujamaa? The concept of ujamaa means familyhood and is based on traditional African socialism. The underlying principles include respect for the rights and place of each member of the community by all members, and the obligation of each member to contribute to the development of the 
community by working hard. Therefore ujamaa means living and working together in communities for the good of all. In order to work together, the people had to be brought together to live in ujamaa villages (Maro, 1983).

\section{Objectives of Ujamaa}

The objectives of Ujamaa settlements, couched in the philosophies of socialism and rural development, were laid out in the 1975 Villages and Ujamaa Villages Act, which specified the following:

1. To build a society in which all members have equal rights and opportunities, and in which all members have a gradually increasing basic level of material welfare;

2. To develop new socialist relations of production based on communal land utilization;

3. To promote a spirit of self-reliance in social and economic activities such as building schools, hospitals, and social services.

The objectives of Ujamaa villages had different interpretations by the peasants and by the government. The great majority of the settlers assumed that the ujamaa policy would enhance their autonomy, and they expected the promised good life to start immediately after they moved into villages. The officials, on the other hand, interpreted the revolutionary objectives as inviting the state to play a major role in transforming the rural areas. Many officials applied the bureaucratic and managerial strategy of command and control in the formation of Ujamaa villages. The command and control strategy sometimes discouraged peasants' voluntary initiative and compliance (Maro and Maro, 1982). 
Implementation of Ujamaa

The strategy used in the formation of Ujamaa villages was spelled out in the document entitled Socialism and Rural Development. A Ujamaa village was defined as a voluntary association of people who decide of their own free will to live together and work together. Such villages were to be established through education and persuasion and not by force. But in 1969, the president of the country issued a circular stating that incentives became important to make people move to Ujamaa villages. From 1973 to 1976 force was widely used for moving the rural population into Ujamaa villages. From the beginning the president proposed three stages: the initial stage, when the people moved so as to live together; the second stage, when the village community had gained some experience of living together and participating in communal activities; and the third stage, when the villagers could be persuaded to become communal farms with small plots and other communal productive activities (Ellman 1970, McHenry 1979).

\section{Structure of Ujamaa Villages}

The objectives and strategies evolved and consequently the concept of Ujamaa villages changed. Though villages formed before 1973 were referred to as Ujamaa villages, they did not have any communal activities. With governmental campaign to move people forcibly to villages, the new villages were referred to as development villages to distinguish them from earlier villages already in existence. In some regions of the country three types of village were recognized: the regular village, which had no cooperative or communal activities; the cooperative village, which had been registered as a cooperative; and the Ujamaa village, which carried on all its operations on a communal basis. The 1975 Villages and Ujamaa Villages Act recognized only 
two kinds of villages: villages and Ujamaa villages. The criteria for being recognized as a Ujamaa villages as set forth by the Act included self-reliance and communal activities. Such villages were required to have constitutions and contain a minimum of 250 families in a defined area. They needed a village assembly consisting of all residents aged 18 and over and a village council of 25 members selected by the assembly. The Ujamaa village councils had to be capable of setting up committees to deal with finance, planning, production, marketing, education, and social welfare. Ujamaa villages needed a chairman and secretary. All land and major machinery and buildings were required to be under the control of the village council. When such criteria had been met, a village could apply for registration to become a Ujamaa village according to the 1975 Act. The Act stressed communal production, to provide a nationwide standard for living and working together.

Formation of Ujamaa Villages and Population Redistribution

In 1967 about 5 percent of the rural population in Tanzania lived in traditional villages, and the majority of the rural population lived in individual scattered homesteads. Therefore, to implement a successful ujamaa policy, most people had to move from where they lived to new villages. From 1967 to 1969, persuasion was used for making people move to new homes. Seminars, meetings, tours and campaigns were organized in different parts of the country to persuade leaders and rural peoples to establish the ujamaa policy.

By 1969 there was a total of 800 Ujamaa villages throughout the country, with a total population of about 300,000 people, representing about 2 to 5 percent of the rural population. The leadership was impatient with slow 
progress, and the promise that ujamaa villages would transform the rural areas was losing credibility.

Between 1970 and 1972, the government began to take a more active role in the formation of Ujamaa villages. While the government increased the incentive for people to move to villages, the 1970 famine struck some regions. The president took the personal initiative of living in such villages and participating in the activities of persuading and helping people to move into villages where they could participate in communal production. As a result of such participation, the number of villages in the Dodoma Region, where the president lived, increased from 75 in 1970 to 246 in 1971. Some regional commissioners did the same thing as the president. With intensified campaigns, the number of villages in the country increased to 4,864 ; and by 1973 about 2 million people, representing 15.7 percent of the rural population were living in Ujamaa villages.

\section{POPULATION REDISTRIBUTION}

The population redistribution differed from one area to another. Between 1967 and 1973 it was estimated that only 1.5 million people were moved to new settlements. But between 1973 and 1976, not less than 5 million people moved to new settlements. Although at the national level villagization involved massive changes in population distribution, at the local level, redistribution generally took place within each administrative region. By 1977, however, the rural population had been collectivized into nucleated land settlements. This was a considerable achievement and one that laid the foundation for rural transformation (Ellman 1970, Mushi 1971, McHenry 1979). 


\section{AGRICULTURAL PRODUCTION IN THE SETTLEMENTS}

Villagization eliminated landlessness in the rural population. The elimination of large individual landholdings, land speculation, and the government requirement that all able peasants must work contributed to the elimination of landlessness. The organization of production on both individual and communal farms increased work discipline among the peasants

The size of the farms, both individual and communal, differed from one area to another, according to the physical environment and the type of agricultural inputs available to peasants. In general the individual holdings were 1.2 hectares as an average, but they could be as large as 5 hectares or more especially in livestock grazing areas. The size of communal farms per household was even smaller. In the years following villagization, especially 1980-1981, agricultural production did not increase significantly. In fact, some export crops, such as coffee, cotton, tea and tobacco, actually declined. Several factors contributed to the decline in agricultural production:

1. Low level of investment in agriculture;

2. The low use of mechanization;

3. Shortage of agricultural extension people;

4. The inadequate marketing and the transportation, and;

5. Shortage of pest control.

Despite these factors, communal farms received official support and enjoyed modern inputs. Communal farms were used to demonstrate the advantages of mechanization, high-yield seeds, fertilizers, and appropriate planting. In some areas, application of these techniques proved that considerable increases in yields per hectare could be obtained (McCall 1985). 
As far as land settlements were concerned, the Tanzanian government made efforts to promote improved rural income. The nationalization of land in 1962 gave almost every Tanzanian equal rights to the use of land, while it also put an end to feudal systems. Since villagization, land allocation throughout the country were controlled by village authorities. This assured every peasant of at least subsistence farming and eliminated the basis for landlessness and extreme poverty.

The Arusha Declaration, on which the ujamaa policy was based, emphasized equitable distribution of income and access to basic social services. The village became the basic center for free primary education, free primary health care, and clean water. The social services helped to reduce ignorance, disease, and poverty in the rural area. The government introduced farm import subsidies and eliminated export taxes. Produce prices, especially for food crops, increased steadily, contributing to increased farm incomes The government controlled prices and established wage, income, and price policy for achieving a degree of equity in income distribution in both rural and urban areas.

\section{VILLAGIZATION AND BASIC SERVICES}

After the Arusha Declaration, the government decided that apart from giving everyone access to productive opportunities, there was a need to provide free basic needs in the form of primary education, health, and clean water, for social justice and as a necessary input for socioeconomic development. The collectivization of the rural population into nucleated 
settlements enabled the government to provide basic services to the maximum number of people at a minimum cost. Such basic services in Tanzania were very successful and very effective in improving the quality of life for the majority of Tanzanian people.

\section{COSTS AND BENEFITS OF LAND SETTLEMENTS}

There were two kinds of financial costs involved in land settlement: the costs of moving people to villages and the cost of providing them with their basic needs. The cost of moving 5 million people has been estimated at about 800 million Tanzanian shillings, and the cost of providing people with their basic needs totalled 300 million shillings. This did not include the costs of social services and infrastructure. These costs were a large burden on the government. The greatest benefit of villagization was the provision of basic services, the availability of education, clean water, and health services, which led to a reduction in mortality and an increase in life expectancy. All this enabled the peasants to engage effectively in productive activities and to improve the quality of their lives. Though the cost to government was high, the establishment of the Ujamaa settlements were positive and apparently justified the costs (World Bank 1977).

\section{CONCLUSION}

The Arusha Declaration settlements that failed were abandoned because they were inappropriately conceived, overcapitalized, and relied on foreign funding. While the villagization program amounted to agrarian revolution, it was hardly possible to exaggerate its importance in shaping the economic, 
social, and political future of Tanzania. There were over 15 million people living and working together in over 800 villages in rural Tanzania. In 1981, agriculture production contributed between 75 and 80 percent of foreign exchange. The Ujamaa village were important as the core of development and well-being for the entire population. The villages as a sociopolitical institutions were established and moving toward full achievement of the goals their establishment intended to achieve. Under their village governments, the villagers were engaged in the cultivation of individual plots and communal farms and in various cooperative productive activities. They were involved in the formulation and preparation of projects relevant to the development of the village. Villages were therefore firmly and permanently established in Tanzania and are presently making a significant contribution to socioeconomic development.

With all the successes evidenced by villagization, several problems are now faced. The most pressing problem in all villages is that of low yields and low productivity in agriculture. Most of the villages suffer from the related problems of incompetent leadership, management, and technical skills. This calls for village-based training in government administration and management, such as bookkeeping, shop management, modern agriculture and animal husbandry. Villages may be much more understanding and accepting of fellow villagers trained in matters of local development rather than government agents of change who may not be sympathetic to village development problems.

Other problems presently experienced by the villages come from the fact there has not been significant transformation in other sections of the national economy, especially industry. This has created serious problems in the supply of inputs, the collection and marketing of agricultural products, and the 
development of infrastructure. The production of consumer goods by local industries was part of the incentive package to distribute goods more efficiently. However, most local industries have failed to produce essential consumer goods in the villages. 


\section{CHAPTER VI}

\section{LAND SETTLEMENT IN ETHIOPIA}

Ethiopia is the third most populous country in Africa, having nearly 35 million people. In 1984 Ethiopia's total land area was 1.24 million square kilometers. With this large area, only 14.8 percent of the country's land area was under cultivation; 50 percent of the total area consisted of grazing land and browsing. Nearly 19 percent of the land was not utilizable for agriculture.

There are three geographical areas in Ethiopia, classified according to altitude, temperature, rainfall and vegetation. The Kolla area, which is the land below the altitude of 1500 meters above sea level with high temperatures throughout the year $\left(20^{\circ} \mathrm{C}\right.$. or higher) associated with low vegetation. Secondly, the Weynadega area, which consists of all lands of 1500-2500 meters above sea level, with medium temperatures and the agriculture in the area dependent on rain-fed crops. Thirdly, the Dega area, which consists of highlands with altitudes of 2500 meters and more above sea level with low temperatures throughout the year.

Ethiopian settlement patterns follow these geographical divisions. Most of the farm people practice rain-fed agriculture, which are located in the Dega and Weynadega area. In the plateau area of Eritrea, Tegre and Wallo, nucleated settlements are common. Closely spaced huts characterize settlement patterns in parts of the Gondas, Gojam and Gamogofa plateau area. In the highland areas, scattered settlements and widely spaced groups of 
huts are typical patterns of settlement. In 1984 about 78 percent of the Ethiopian population lived in the Dega and Weynadega area because the highland areas had good volcanic soil, favorable temperatures and high rainfall.

The lowlands, as in the Kolla area, have a very low population. The Kolla area covers about 60 percent of Ethiopia's land area. It has harsh climatic conditions; high temperatures throughout the year, insufficient rainfall, low vegetation, and debilitating hazards such as malaria and the tsetse fly. It supports a mainly nomadic people, who accounted for nearly 10 percent of the total population in 1984 (As-Faw 1975).

The settlement patterns in Ethiopia are not well-balanced. Concentrations of large numbers of people in the highlands have put great environmental and economic pressure on the land. Land fragmentation resulted in low agricultural productivity and landlessness (Kassaye 1978).

This bad situation was made even worse by the droughts in 1972-73. The droughts served as an impetus to focus public attention on relief aid for the survivors, while it also encouraged policy makers to think in terms of longterm solutions, mostly concerning the resettlement of those for whom there was no hope of making a livelihood on the land that had been ravaged by drought.

In 1941, after the expulsion of the Italian occupation forces, large tracts of land, particularly in the southern regions, were claimed as government land. These constituted the bases for settlement programs in Ethiopia. Emperor Haile Selassie distributed land to patriots, prewar soldiers, public servants, and some landless and unemployed people. The Emperor used his powers not only to grant government land as he wished but also to change the status of landholdings from one form to another. He made many authorizations 
for the conversion of temporary usage rights to land into freehold usages. Such powers by the Emperor to develop land administration did not always result in beneficial settlement patterns.

Political gains were given more consideration than long-term economic gains. Many grantees did not themselves settle on the land but kept title to it. Others used their ownership privileges to maintain tenants and gain profits. Often the beneficiaries of the grantee system were landowners. The system therefore had the effect of accentuating the inequality of incomes and giving more powers to landowners. The landlord-dominated parliament failed to develop any reform in agriculture, which remained backward and faced declining productivity. These conditions were not isolated only in the Ethiopian monarchy. Unfortunately they were a duplication of the conditions in Iraq during the King's reign after it had gained its independence from the English colonial forces following World War II.

In 1966 the Ministry of Land Reform was established, charged with the task of formulating appropriate land reform policies. Among its priorities was the adoption and implementation of settlement and resettlement programs. The government attached great significance to the settlement issue, both to solve the problems of a too-high labor to land ratio in the northern plateau regions and modernizing agriculture and increasing productivity and the economy as a whole. In 1971 a consultant advisory group from Harvard suggested repeal of the land grant system in Ethiopia and proposed a comprehensive planned utilization of government lands through sound and appropriate settlement policies.

Another problem identified by the advisory group report of was excessive spontaneous settlement. This coincided with earlier studies by the planning commission which concluded that spontaneous and unorganized 
settlements were not a very good means of improving agriculture production. The Ministry of Land Reform and Administration saw settlements as an important development strategy. Soil studies by the ministry found government land that could be used for settlement was rather limited. Large areas of the land were located in arid regions with very small prospects of irrigated agriculture. Other areas were located in remote regions, covered with forest and swampy land, which could be very costly to develop. However, the government was overthrown in 1974, before any working land policy and program could be implemented.

There are two types of settlements in Ethiopia; spontaneous and planned Spontaneous settlements started in 1942 by movements of very large numbers of people. A number of factors precipitated the development of spontaneous settlements. These included (1) high rates of population increase throughout Ethiopia, including the northern plateau, which already had high population densities; (2) little opportunity for landownership in the northern region of the country; (3) large scale evictions of tenants from the land in the central region as a result of commercialization and mechanization; and (4) improvements in transportation and communication and the government's land grant system, by which large numbers of grantees were encouraged to settle in new areas. A study carried out in 1975 by Wood observed that spontaneous resettlement had become widespread in Ethiopia during the prior three decades.

Planned settlements in Ethiopia started after the overthrow of the monarchy government in 1974. However, there were three five-year development plans, the first of which (1957-61) did no more than mention the need to use settlement programs to improve agricultural productivity. The second five-year development plan (1963-67) did not produce any new 
development in the planned settlement, but it was recommended that studies be conducted to pave the way for an effective land settlement program in future years. In the third five-year development plan (1968-73), settlements were viewed as a regional development strategy to relieve population pressures in the northern plateau regions, increase agricultural productivity through the use of underdeveloped land resources, and improve land management practices. This was the general picture at the national level.

At the local level the first known planned settlement was started in 1958 by the governor of the Sidamo region. The purpose was to bring under cultivation lowland areas that were only in marginal use. A further aim of the settlements was to resettle surplus people from the overcrowded highlands, Welamo and other similar areas. These settlements were later passed on to the Welamo agricultural development unit when it was established in 1970 under the Ministry of Agriculture to implement a regional development program. Several other settlements followed these sponsored ones. These early settlements were conceived as low cost, labor intensive projects in which government inputs were kept to a minimum. There was careful selection of the settlers, and there was provision of a demonstration program as part of the agricultural extension service (Wetterhall 1972).

A real change in increased planned settlements took place with the establishment in 1974 of the Relief and Rehabilitation Commission, a direct consequence of the 1972-73 famine that claimed many thousands of lives.

A significant event in facilitating the process of settlement was the 1975 Proclamation, which nationalized rural land. The public ownership of rural lands made it possible for the government to resettle people as needed. In addition, it cleared the way for setting up peasant associations. The other important development was the establishment of settlement authority in 
1978 as a unit within the Ministry of Agriculture and Settlement (Simpson 1975).

The priorities of such authority were the settlement of unemployed people, displaced groups, landless persons, and nomads. According to its planned programs, the settlement authority was to provide settlers with agricultural inputs on a credit basis, loans for setting up cooperative organizations, a water supply, health care, and education. The cooperative organizations, which were part of the scheme for achieving self-reliance, were to be owned and managed by the settlers themselves. The settlement authority set a target of settling 20,000 families per year. Actual settlement was less than expected, constrained by developments that led to further reorganization of the settlement programs. The Proclamation of 1979 set up a new Relief and Rehabilitation Commission. This commission was to bring under one organization the tasks that had been carried out by three different agencies, namely the Awash Valley Authority, the Settlement Authority, and the Relief and Rehabilitation Commission. It was a body accountable to the office of the chairman of the Council of Ministers and was given wideranging powers and duties in the settlement program. As of 1983, there were 85 planned settlements.

\section{OBJECTIVES OF PLANNED SETTLEMENT}

There were many objectives of planned settlement to be achieved: to make use of and develop idle land and water resources; to provide income and activity to unemployed people and peasants suffering from the drought; to accommodate landless farmers in settlements; to shift people from overcrowded areas to better settlements; and additionally, to settle the 
nomadic tribes. In general the settlement programs were directed at three target groups: First, the urban unemployed groups of people of working age and in need of productive jobs. As in most third world countries, the problem of urban unemployment in Ethiopia was in the alarming range between 10 and 20 percent. The second target group consisted of those who had been displaced due to drought. These were inhabitants of the highland regions of Ethiopia where the soil had been depleted of its fertility due to mismanagement, poor soil use practices, and recurrent drought. This target group included thousands of families without any resources for their livelihood.

The third target group encompassed the nomadic people. They made up about 10 percent of the total population of Ethiopia. The earliest planned settlements for the nomadic people were in the Awash Valley under the old Awash Valley Authority. However, a better concerted effort to settle nomads was made by the Relief and Rehabilitation Commission in 1983, which settled some 7000 nomads in 15 settlements. These numbers made up about 21 percent of all settlers and 18 percent of all settlements in Ethiopia. The reasons for such planned settlement by the Ethiopian government were recurrent drought and dislocations.

\section{The Settlement Process}

The Relief and Rehabilitation Commission started with the identification and selection of target groups. Then the Commission made each target group understand the advantages of involvement in a settlement program. The type of group the Commission looked for was a family belonging to the 18 to 45 age group, in good health, and a willingness to live by the Commission rules. Once heads of families registered, a feasibility study 
of the selected settlement site was conducted. This included a study of its location, climate, geology, soils, topography, vegetation, water resources, communications, and land use. The study was carried out by a team comprised of an agronomist, agricultural engineer, agricultural economist, geographer, animal husbandry specialist, and sociologist. The study included development of a general plan on how and when the various important targets were to be realized. A detailed plan was established that set up a work schedule for every operation, including necessary material, financial, and manpower requirements for the fulfillment of the operation. The planning stage of the program was then completed and the implementation started. The final stage involved assessing the program and making modifications throughout implementation.

The Relief and Rehabilitation Commission was given the task of settler selection. The Ministries of Agriculture, Interior, and Labor and Social Affairs, as well as the peasants' associations, were expected to participate in recruitment of people for resettlement. In principle, no one was chosen for a settlement program unless he/she volunteered for it.

\section{The Settlement Model}

The scheme of the Ethiopian settlement model set forth an objective that each settlement unit be composed of 500 families. Five such units made one project area with an office of administration and management to coordinate its activities. The first settlers were accommodated in common shelters; later they constructed their own dwellings. Each settler was given one 1000 square meter plot on which to construct his homestead. The settlers were provided with food, clothing, and other essentials until they attained self-sufficiency.

Self-sufficiency in food was expected to be attained after only two 
seasons. However, in instances where this was not attained, governmental food aid covered the difference between actual production and food requirements. Expenses incurred for livestock development were expected to be repaid. However, money expended on investments for development works, including building for livestock development, did not require repayment.

Settlers were organized into producer cooperatives. Within the first year it was anticipated that the settlers would be introduced to the basic principles of cooperative farming. The leaders of the cooperatives would be given some education in cooperative management, job assignment, and income allocation.

Each settlement was expected to have a unit manager, a cooperative organizer, an economist, a mechanic, and an assistant administrator. In total, 14 skilled persons were assigned by the Relief and Rehabilitation Commission. Over a three-year period, settlers were given training in the field of agriculture, cooperative management, health, and economics. A settlement project was expected to achieve self-sufficiency in three years. At the end of the third year, a team of experts from the Relief and Rehabilitation Commission and the Ministry of Agriculture would determine whether selfsufficiency had been attained. If the conclusion was positive, the Ministry of Agriculture would take over administrative control; if not, the Relief and Rehabilitation Commission would run the project for a few more years.

\section{THE SETTLEMENTS SCHEME ACHIEVEMENTS}

About 95 percent of Ethiopian settlements were run by the government. The land allocated for settlements was considered choice land with enough 
moisture and good soil conditions. The government therefore expected the settlement schemes to yield high levels of land and labor productivity. Actual performance has been far below expectations (Wood 1977).

\section{CONCLUSION}

Ethiopia, like many other Third World countries, has a population that is unevenly distributed. For example, the high plateau area has high population densities, with depleted soil and very poor environment, while the lowlands area, which has a great potential for irrigated agriculture, is underpopulated. One of the planned settlement policies was to take a measure of population relocation, and the second objective was to make better use of land and water resources.

The settlement of nomads, a reduction in urban unemployment, and the development of agriculture for cash crop production including exports, were too costly. The settlement program faced serious problems, such as mismanagement and low land and labor productivity. The lack of sufficient time to prepare, plan, and implement settlement programs was a cause of high costs. This situation was expected to improve if political stability increased and the conditions of drought improved.

The alternative settlement model has its own advantages, which show that low-cost settlements are in general terms more cost effective and more efficient than special settlement schemes. Therefore, it is essential to make the low-cost settlement option a viable proposition in future settlement programs.

Settlement costs must be brought down to the cost levels of producers, cooperatives and other different competing forms of agricultural production 
units. Among such cost-reducing steps, careful selection of settlement lands and settlers, and least-cost execution of settlement schemes may prove beneficial. The introduction of incentives, the provision of inputs and training, and the guarantee of good prices for all settlement products may also contribute to the success of settlements.

There are many other measures that could contribute to lowering the cost of settlements, such as good services, favorable marketing, and improved transportation. All these together, with improved management of settlements may lower their costs of operation. Under the present practice, settlers are made totally dependent on the government, which provides free food, transportation, equipment, training and other services. This in part is responsible for the high cost of settlements. An alternative scheme of settlement might be considered such as voluntary settlements, and a partnership between settlers and the government in sharing costs and other responsibilities. 


\section{CHAPTER VII}

\section{RESETTLEMENT OF NOMADS IN SOMALIA}

Geographically, Somalia is a land of rolling savannah with high areas in the north located east of Ethiopia on the Gulf of Aden. It has two rivers, both coming from the Ethiopian highland. The land between those rivers is very fertile and the most well irrigated in the country. Generally, Somalia is considered arid or semiarid; low rainfall and droughts are common.

Somalia has a population around 6 million in 1970. About two-thirds were nomads in an area about 637 to 657 square kilometers. The 1974 drought caused large migrations of nomadic people from the rural areas to the cities in search of water and food (Mohamed 1977). In 1975 the government established about 20 relief camps. The total population of these camps was estimated around 300,000 people. During the desperate period of the drought an estimated 20,000 people, mostly children and elderly, died. Furthermore, the drought killed half of Somalia's nomadic sheep and goats, a third of its cattle and about 120,000 tons of food grain.

When the seasonal rains returned, most drought-stricken nomads returned to the rural areas to rebuild their lives and herds. The Somalia government decided to resettle those who remained in permanent agricultural and fishing settlements. About 15,000 settled in three fishing settlements and about 105,000 settled in three agricultural settlements. Establishing permanent settlements for a large number of settlers exceeding 
100,000 people was a very hard task. Because of the complex nature of the job, the government decided to create two independent agencies to be in charge of the development of the settlements. Thus in 1976, the Settlement Development Agency and the Coastal Development Project was created.

In the period from 1975 to 1977 , the settlements were run as extensions of the relief camps. The new agencies decided to upgrade the services such as medical facilities, building schools, digging wells, building food storage, and creating administrative centers to change the camp's character. Land clearing started immediately and crop cultivation started at the agricultural settlements before the end of 1975 . The period was one of crucial readjustment for the nomadic settlers, as well as for the new agencies. However, many settlers left and returned to their herds and pasture lands. The settlements as a whole lost about 40 percent of their population. In 1976, the arrival of modern boats and the construction of permanent housing and processing facilities was the cornerstone to stabilize this drift at the fishing settlements.

\section{THE RESETTLEMENT POLICY}

The main objective of the resettlement policy evolved since 1974. However, the international aid to Somalia in response to the drought focused closely on two important issues. First, to redistribute Somalia population to avoid and reduce the rangeland deterioration, and reduce urban growth by developing productive rural enterprises. Through developing large scale irrigation projects and coastal and deep sea fishing schemes, the government hoped to diversify the country's economy in order to achieve national selfsufficiency and reduce the country's trade deficit. Second, to provide social 
services to a large number of nomadic population, and to deal with Somalia war refugees.

\section{The Nomad Resettlement}

The Somalia government established six nomad settlements, three of which were fishing settlements. These were Eil, Adale, and Brava. The first two fishing settlements were located north of Mogadishu and the third south of Mogadishu. The three agricultural settlements, Dujuma, Kurtunwary, and Sablaale, are south of Mogadishu. The agricultural settlements were much larger than the fishing settlements; the former had 17,000 to 25,000 settlers, while the fishing settlements had 3,000 to 5,000 settlers.

\section{Organization of the Settlements}

The organization was established at three levels: the Settlement Development Agency and the Coastal Development Project (their headquarters were at Mogadishu); the settlement management organization; and a sociopolitical structure within the overall framework of the provincial administration.

Each settlement had its own management headed by a manager who was responsible for day-to-day operations. He was supported by a team of professional officers heading the departments of agriculture, livestock production, forestry, and farm administration. Because of the nomadic origin of the settlers, a high level of supervision was very essential; that was why junior staff supporting the senior management were needed.

\section{Settler Characteristics and Training}

Since 1975 resettlement meant a change in occupation for nomadic 
people who had been drought-affected. A considerable training effort by the agencies administering the resettlement was required and essential. The Settlement Development Agency undertook an extensive training program. While awaiting the arrival of mechanized machinery and equipment, the Coastal Development Project concentrated its training on the use of modern boats.

Training on both types of settlements was necessary to provide the settlements with engine operators, mechanics and net menders. In addition, processing workers and administrative workers were important for a settlement's survival. The training provided by the Settlement Development Agency included an adult literacy program for those who had no formal schooling. Skills training was also provided in agriculture, construction, handicrafts, clerical work, transport, communications, and health care.

\section{Income and Work Incentives in the Settlements}

At the inception of the settlements the government was providing all services and facilities, such as food, clothing, and housing. Most settlers in agricultural settlements received their rations and a small daily cash incentive per day of about 2 shillings. Such incentive were tied to the work done. Those given skills training received more, about 10 shillings per day, according to the skill acquired and their occupation. Fishermen in the fishing settlements received a cash incentive on a standard 0.80 shilling per kilogram of fish caught.

The work attitudes of the settlers had serious implications for the planned self-sufficiency of the settlements. Throughout the settlements, absenteeism was very high and productivity low. Such conditions became a matter of concern; various alternative ways of encouraging productivity were 
considered. One possibility was to increase cash payments, but the government could not afford such an increase. Another alternative was to create cooperatives and turn the settlements over entirely to the settlers, but the drawback of such an alternative was the question of whether former nomads could handle such responsibility with any hope of success.

The most promising possibility was to provide input, extensions, and marketing services, while the household was to be responsible for generating its own income and responsible for bearing the cost of the services provided by the agency.

\section{ASSESSMENT OF SOCIAL STRUCTURE AND INFRASTRUCTURE}

In general terms, the progress achieved in providing facilities and social services in the three agricultural settlements was impressive. In the fishing settlements, it was even more advanced.

The housing projects at the agricultural settlements proved controversial. Many officials argued that housing would be better provided by the settlers themselves, and the settlement agencies' first priority should be to make the settlements economically viable. The argument was that when incomes in the settlement increase, the settlers themselves would build their own housing. While the housing projects were certainly an attraction that might have served the government's goals to retain the former nomads in the settlements, only the promise of a higher income could ensure the settlers' commitment to the project.

Education and health care at the settlements appeared to be above the national norm. Healthwise, care also appeared to be more than adequate in the agricultural settlements, because each settlement had a lower ratio of 
persons per dispensary than the national average, while the fishing settlements had access to the medical facilities at their nearby towns.

The Somali government had some reservations about food rationing supplied by the government, the European Economic Community, and World Food Program. There was speculation that the short-term effects of providing free rations as well as housing would be a loss of incentive for the resettled people to work hard. The long-term effect may have been too much dependency on the state assistance. That is why the rations were phased out at the end of 1984.

\section{Population Redistribution}

The population redistribution in Somalia was an important issue for the future of the country. That was why the agricultural sector was required to carry the brunt of any major population redistribution. The government was placing greater emphasis on large scale irrigation projects run as state farms rather than replicating the Settlement Development Agency schemes, which in terms of production incentives appeared to be moving away from the state farm model.

The World Bank Review suggested the agricultural sector could absorb population increases for the 20 years from 1980 to 2000 based on estimates that 85,000 hectares of irrigated land would be developed and another 750,000 hectares of land would be added to the rain-fed agricultural land. If the agricultural projects are completed, Somalia could well meet and even go beyond the World Bank target (World Bank 1983). 
While Somalia has great potential for fishing and agricultural resources, its rangelands are rapidly becoming overpopulated and overgrazed. This surplus population must be distributed to other areas of the country. The 1974 drought dramatically increased the overstocking and mismanagement of the rangelands. Unfortunately, the subsequent range management and nomad resettlement programs have been less than successful in slowing the deterioration of the rangelands.

In 1979-80, the drought and war arrived at the same time. That meant a considerable additional burden of livestock and human refugees for the rangelands to support. The urgency of relieving the pressure on Somalia's rangeland is greater than ever, and the Settlement Development Agency and the Coastal Development Project resettlement programs are the only experience the Somalia government has in attempting to redistribute the population to achieve better use of resources and manpower.

Unfortunately, the Settlement Development Agency and Coastal Development Project have not been economically effective for many reasons:

1. There was little comprehensive planning;

2. Inadequate management;

3. Social services and housing were very expensive and not cost effective;

4. Little incentive for production.

In general, a lack of policy and planning remains as one of the foremost obstacles. As with the range management projects, and with Somalia development efforts, project implementation and evaluation have continued to be adversely affected by the lack of working documents, such as reporting 
and recording. This condition and difficulty has made it impossible to define development stages and strategies for long-range planning to meet ultimate objectives.

From a social point of view rather than a narrow economic view, the overall performance of the settlement might not be unreasonable. This is especially true if the nonquantifiable benefits of the schemes are taken into account. The resettlement and creation of employment opportunities for many nomadic families. Creation of a social infrastructure that has improved hygiene, nutrition and education opportunities for such people as well as helping them to acquire agricultural and fishing skills they did not previously possess. These suggests that planning is crucial to the success of future resettlement programs. 


\section{CHAPTER VIII}

\section{LAND SETTLEMENT IN MALAYSIA}

The Malaysian program of land settlement started in the mid-1950's as a basic strategy for improvement of the economic status of the rural poor (Bahrin, Perea, and Lim 1977). Within about 30 years, the program received worldwide attention for its style of implementation and overall performance, in which large tracts of land were developed and occupied by previously poor and landless farmers. Farmers who settled in the large tracts of land became possessed of relatively good income, compared with those who remained in the old villages.

The Malaysian resettlement program differed somewhat from other Southeast Asian programs. It was not intended as a population redistribution measure, but was essentially aimed at improving the socioeconomic status of the participants. Nor was it implemented as part of a more comprehensive rural reform. The program schemes generally used land for growing cash crops, especially rubber and palm oil, rather than subsistence food crops. The manner of implementation also differed somewhat from other programs. The Malaysian settlers were not required to engage in jungle clearing, thus making the projects relatively more capital intensive. 
The land ownership in Malaysia was under the ruler-in-council, and any issue of land titles for such lands had to be conducted through the ruler. However, demand for land was very great on its Moxeman Height. At the time of independence, August 1957, there were some 200,000 land applications awaiting action.

A Committee was set up by the government for action. Action included processing land transfers and making recommendations for improvements and developments. The Committee report observed that the scheme of land transfer in Malaysia was commonly causing much work, confusion, taking a great deal of time, costing a lot of money and producing the poorest economic results for the individuals concerned and for the community as a whole. One of the causes of this situation was the initiation of land applications by individuals rather than by organizations or agencies that could be expected to have a better understanding or to have an overall view of the selected area. Almost every application was made for personal gain, without the least regard for public interest. Under these conditions, applicants who had money and knowledge about application procedures were in a more favorable position to obtain land than those who really needed it.

Under the system, land development initiated by the applicants and not by the administration was not the action desired by the Committee. The Committee was of the opinion that land ownership transfer should be initiated by the State to avoid haphazard settlement. It was recommended that areas of land suitable for development should be identified and an initial appraisal of the area for its economic viability made before dividing it into suitable units. It was also thought that in appraising each parcel of land 
before receiving any application, it would be proper to include provision of basic amenities such as roads, schools, health services, water and other facilities. An approach of this kind indicated a system of planned settlements.

The Malaysian government set up a working party early in 1955. The working party emphasized the need for land resources to be assessed. Large areas for new development would be allocated only after being planned. The working party recommended an emphasis on the need for planned and coordinated development of land to insure that economic development proceeded in accordance to social development goals. The working party also suggested that development activities be coordinated and controlled to insure that division of holding does not occur, and that the settlers have an adequate amount of land and a good standard of living.

The Committee members also recommended that an organization be created to implement the development program. They suggested that a federal authority with powers of financing and carrying out individual projects would be too remote from the state and the people who were to be assisted. It therefore suggested that the organization for providing federal assistance for land development schemes be decentralized Local development authorities, set up by the ruler-in-council for each project, would be responsible for the planning and execution of the projects. The Federal Land Development Authority was to be involved only when a local authority had decided to carry out a project.

Such a system had some weaknesses, for example, too slow a pace in opening new projects during the initial period. In view of the slow pace and limited achievements by the Federal Land Development Authority, the Malaysian government set up a committee in 1960 to investigate the reason for the lack of success and to review the role of the Federal Land 
Development Authority. The committee gave some reasons for the limited success:

1 The lack of a sense of urgency in land development matters on the part of several state governments and their consequent slow response in proposing schemes.

2. The lack of basic land use surveys and consequent absence of plans for land development.

3. The lack of access to potential development areas.

4. A shortage of qualified and experienced staff to supervise and manage land development schemes. (Tunku Shansul Bahrin 1968, 1977).

The committee felt that to meet the increased demand for the proposed land development fifteen different agencies for land development projects, including Federal Land Development Authority, which was the largest, had to be employed.

It is essential to understand fully the process of land settlement in Malaysia. It is essential to discuss the other types of land development schemes planned and implemented during the 1960's, namely, the group land settlement and the fringe land ownerships.

\section{GROUP SETTLEMENT SCHEMES}

The group settlements were small sized settlements financed and implemented by the state governments. They came into being with the implementation of the Settlement Acts of 1961.

The group settlement had some flaws. First, the settlements were in remote locations because it was hard to find a 2000-hectare area near towns and villages. Second, there were no subsistence allowances. The settlers were 
forced to find alternative sources of income outside the settlements. As a

result, the settlers were unable to carry out full-time work on their holdings. Third, because of the shortage of housing facilities, the settlers tended to live on their holdings rather than in the prescribed village area. This made it difficult for supervision. Finally, the area held by each settler was too large for the average family to develop, and the tasks became more difficult without any financial assistance from the state. Because of all these difficulties and weaknesses, all states quickly abandoned group settlement projects.

\section{FRINGE SCHEMES}

Fringe schemes were implemented by the state governments but financed by federal grants and loans. The idea behind these projects was to supplement existing holdings that were economically unsound. They were therefore established near agricultural settlements.

The fringe schemes intended that the participants were to be farmers who already owned holdings that were not economically profitable. Those holdings considered uneconomic were ones less than 3.6 hectares in area. As the projects were for people already in possession of some agricultural land, they were expected to work on the projects on a part-time basis while continuing to farm their own holdings. The Malaysian government decided to allocate $49,560,000(\mathrm{M} \$)$ as a federal subsidy for the establishment of such projects for the period 1960-70. The money was to be provided in the form of loans and grants to cover the costs of clearing land. The loans were not to exceed (M\$) 815 per hectare to meet the cost of specified items, and interest was to be charged at a rate not exceeding $5 \%$ per year, over a period of six 
years. In addition to the loan, a grant was to be made by the federal government of about (M\$) 647 per hectare to cover the costs of material and fertilizers.

By the end of 1970, 423 projects had been established, covering an area of 64,660 hectares with 26,104 participating families (Tunku Bahrin 1976). The overall performance of these projects can be generally described as disappointing. The federal government was so dissatisfied with the projects that it had to create a new federal authority (the Federal Land Consolidation and Rehabilitation Authority), with the major function of helping and redeveloping those failed projects.

\section{IMPLEMENTATION AND SETTLER SELECTION}

Since 1950 the government had been aware that settlers were the most important factor in implementation and determining the success or failure of its programs. The Federal Land Development Authority tried a number of selection systems to insure that it obtained the right type of settlers. For 28 years the Authority has instituted a number of changes in its selection system, however, according to its formalized selection system, prospective participants had to submit their applications on prescribed forms and meet these requirements:

1. Malaysian citizens;

2. Aged 21-50 years;

3. Married, preferably with children;

4. Landless or with rural holding of less than 0.8 hectares;

5. From an agricultural background, and;

6. Physically fit. 
Applicants who met the requirements were first interviewed, then accepted on a points system. The most points were awarded to those who were landless, with large numbers of dependents. The maximum score was 100, and any applicant obtaining a score of less than 50 points was disqualified.

\section{Development of Land}

Malaysia had considerable land available for development, but the choices of land for settlement was not simple and easy. Almost all land that was suitable for agricultural development and in close proximity to transportation and other communication had already been utilized. The state governments owned most unoccupied land. The Federal Land Development Authority had to negotiate with state governments to secure release of any land for settlement. When agreement had been reached with respect to location, suitable crops, and survey fees, the state government declared the land a development area. Once declared a development area, the land was then turned to the Federal Land Development Authority. Most settlement sizes per project were 1800 hectares for 400 families. The size of holding per settler family on the other hand was governed by income and employment factors. Each settler family was given 4 hectares of agricultural land and a piece of residential lot about 0.1 hectares in size.

\section{Pattern of Settlement Development}

The pattern of pre-1966 development under the Federal Land Development Authority scheme for settler families occurred in different phases. The first year was devoted to the felling and clearing of trees for the establishment of an approximate 300 acre (120 hectare) village area and the planting of about 1000 acres ( 400 hectares) of the main crop. Land remaining 
for the main crop was developed in subsequent annual stages of approximately 1000 to 1500 acres (400-600 hectares). The subsidiary crop areas were developed at a later period, as decided by the Federal Land Development Authority, subject to the progress made in the development of land for the main crop. This pattern was known as phased development. Since 1966, this pattern has changed over to the development of larger areas.

The government's desire to speed land development made it imperative that larger areas for agricultural development be made available. The emphasis on palm oil also made the development of larger areas desirable in order to realize the economic benefits of such scale. In the past, logging delays had prevented the land from becoming rapidly available. But increasing demand for tropical timbers and increased logging and clearing rates made it easier to obtain larger areas. With an increase in management, it was possible to develop larger areas.

\section{LAND DEVELOPMENT ACHIEVEMENTS}

The Federal Land Development Authority in Malaysia was considered the most important agency in the field of land settlement. This was clearly recognized by the government, as seen by the land allotted for development. By the end of 1982, the agency had implemented 331 projects comprising a total of $1,383,528$ acres $(559,906$ hectares) of agricultural land and 93,527 acres ( 37,850 hectares) of urban and residential land. Palm oil and rubber were the major crops, occupying some 60.6 and 29.3 percent of the total agricultural area, respectively.

The Federal Land Development Authority made a number of significant contributions to the development and diversification of agriculture in 
Malaysia. The area developed and maintained by the agency made up 12 percent of Malaysia's cultivated land. Although it helped to create communities and prosperous small scale rubber producers, the expansion in the cultivation of palm oil is considered one of the Authority's greatest contributions. By the end of 1982 , the agency had relocated 43,978 settlers on its palm oil projects, producing 4,734,605 tons of palm oil, representing about 30 percent of Malaysia's total production. This most significant contribution successfully showed that traditional farmers could be turned into modern agriculturalists if given the right guidance and opportunities (Chan 1983).

\section{CONCLUSION}

Malaysia developed a satisfactory land settlement program. During the 30 years since its inception in the mid-1950's, the settlement program became a significant tool for the economic development of Malaysia. In addition, the programs attracted a great deal of attention from many countries who were involved in similar programs. This does not mean that their program was perfect or solved all the difficulties of the rural areas of the country. The Federal Land Development Authority by the end of 1982 had been able to resettle only about 76,782 families and develop 599,900 hectares; many more applications were waiting to be processed and new demands and challenges emerged, awaiting solutions.

Overall, it would be reasonable to conclude that the land development program in Malaysia, as planned and implemented, achieved the objectives formulated in the mid-1950's. It can be said that the achievements were beyond expectation. 


\section{CHAPTER IX}

\section{LAND SETTLEMENTS IN THE PHILIPPINES}

The Philippines have experienced extended periods of resettlement, almost more than any other country in Southeast Asia, including both government sponsored and spontaneous settlements. However, the resettlement schemes in the Philippines may be reviewed in three stages: the colonial period of Spanish rule, which developed a tradition of agricultural production oriented toward export crops; second, an American colonial period; and third, a period of settlement during the independence period (1946-60) (Paderanga and Pernia 1983).

\section{SETTLEMENT POLICY HISTORY}

The American policy during the colonial period had three major goals. First, integrate the Philippine economy into the U.S. market. That was done by lowering the barriers to trade between the two countries. The second aim was an attempt to rationalize land ownership. The mixture of the remnants of the Spanish system with a different method of land management and registration under the United States led to friction between landowners and tenants, which caused conflicting claims to ownership of land. The United States issued new laws regulating the possession and ownership of land. These laws provided for the disposition of public land and introduced the 
homestead concept. The third objective of the U.S. government was a conciliatory policy toward and amalgamation of the non-Christian population, especially in the south. This approach was pursued to encourage people from the north and central parts to settle in the frontier regions.

Direct government involvement in settlement programs started when it adopted a policy of actively encouraging migration in 1913. It established agricultural settlements that offered free transportation and financial assistance. From 1913 to 1917, nine such settlements were established, covering in area about 12,760 hectares. Government policy makers sought to encourage homesteaders to migrate from congested areas into the interior and southern parts of the Mindonao area. They hoped it would lead to integration and Pilippinization of different ethnic groups in these areas. These settlements were in general unsuccessful, because of a lack of funds, illchosen sites, and unwise selections of settlers.

In 1917, the government, discouraged by the high costs and lack of success, retreated from its policy of sponsored settlements. The program was replaced by one that merely encouraged the movement of migrants who could support themselves for at least six months in the settlement area. Apart from transportation and guidance regarding the final destination, no support was offered. Up to 1935 the quantitative impact of these early programs was very small (Sim Kins and Wernstadt 1968).

The period of 1935 to 1946 was one in which the established Commonwealth government maintained the policy of encouraging settlements in thinly populated areas. Because of past mistakes, they concentrated on building up infrastructural support in the target areas, such as the frontier regions. Funds originally allotted for direct expenditure on agricultural settlements were diverted to road construction and land survey. 
In the same time period, the government passed the Commonwealth Act, which established the National Land Settlement Administration (NLSA). Under the NLSA many families moved to settlement areas at their own expense. The administration found it was difficult to turn back these families, which led to a rapid growth of population in the southern frontier, especially in Mindanao.

The third period of settlement, during the independence, exhibited a different set of priorities (Pelzer 1946). Whereas colonial policy dictated close integration between the Filipino government and the United States, political autonomy in the Philippines decreed the economy of the country should stand on its own as much as possible. For the Philippines, this implied that a larger proportion of the industrial products it consumed would have to be generated from within. The unifying aim was industrialization, with import substitution as the main strategy to be followed. The policies used to implement this strategy were exchange and import controls. Rather than adjusting the overvalued peso, policy makers regarded it as an instrument to direct capital funds to preferred industries at subsidized rates. To maintain the official rate, the use of foreign exchange had to be controlled and a system of priorities instituted. Import substitution industries such as textile and appliance manufacturing were favored.

Tax incentives and a comprehensive restructuring of tariffs were also used to achieve the overall objective. The final policy of the period was to raise the minimum wage; its unintended result was to discourage laborintensive industries and further bias investment toward capital-intensive import substitution industries. It was very sad that among these policies was a very strong disincentive to the agricultural sector. The overvalued peso, together with the bias of foreign exchange and controls toward import 
substitution, effectively penalized the export-oriented agricultural cash crops on which the growth of the agricultural sector had been based before independence. At the same time, the ability of the agricultural sector to shift forcefully to the production of food for the domestic market was effectively blocked by the bias against the sector contained in the selective credit instruments, and the policy of subsidized importation of some commodities including food products, aimed at lowering food prices in the urban centers.

Biased production techniques hardly changed for many years. Until 1960 almost all agricultural growth came not from increased productivity but from increases in the area of the land under cultivation. Such increase was possible only because of the intensification of frontier region settlement. World War II interrupted the settlement activities of the government, but they resumed soon after, especially in the frontier area, when the applications increased sharply immediately after liberation as new migrants squatted on former Japanese plantations. In 1971 the Law of Agrarian Land Reform Code was amended, outlawing share tenancies and regulating land ownership and agrarian relations. This law created the land resettlement program as part of the general program of land reform (Renaud 1981). In 1983, the Bureau of Resettlement of the Ministry of Agrarian Reform had been able to develop about 736,969 hectares of land and resettle 52,728 families.

\section{CONCLUSIONS AND POLICY IMPLICATIONS}

The major conclusion obtained from the Philippine experience was that a land settlement program alone cannot solve social and economic problems. The program of settlement was successful in population redistribution and growth of agricultural output, but failed in one important objective, the 
pacification of cultural minorities. Finally, the most important lesson to be learned from this analysis, which is indirectly related to land settlement schemes: a significant cause of the problems that land settlement programs were called to address were the broad macroeconomic and trade policies that had tremendous impact on the demographic configuration of the Philippines. These same policies also tended to negate the long-term benefits that could be expected from the various settlement projects. Unless changes are made in these more fundamental policies, the ultimate benefits from land settlements will be very small or negligible. 


\section{CHAPTER $X$}

\section{SETTLEMENTS IN ISRAEL}

Israel is considered a pioneer state with large and extensive experience in land settlement planning and implementation. As mentioned in the introduction, land settlements continue to be a high priority in many countries to utilize uncultivated and sparsely populated areas as part of rural development. The discussion here involves case studies of two settlements in Israel which had unique conditions pertaining to type of land use, initiative, institutional characteristics of the promoting agency, and orientation for good self-management. The study was done by Yair Levi (senior researcher at the settlement study center, Rohovot, Israel) and Gedalia Naveh (senior research associate at Columbia University in New York, 1983).

The study was conducted to find settlements that had differed significantly from each other in their development, mainly with respect to two important aspects: first, the delegating of the authority from an external team of change agents to the settlers; and second, economic consolidation. The two settlements that met these requirements were also found to share a number of features, such as the settlers' country of origin, the arrival time in Israel and to the settlement, the type of farm, the allocation of production and the kind of assistance provided by the settling agency. These two settlements were selected from a total of 31 Moshvei ovdim (small holder cooperative settlement) in Israel. 
Located close to the northern line of Lakhish region and about halfway between Ashkelon and the town of Kiryat Gat, this settlement was one of the 14 settlements that make up the Lakhish regional council and one of the five Moshvei olim (immigrant moshav) served by the Nehora rural center, where the offices of the regional council were located.

OTZEM was the first settlement established under the program of regional settlement based on the composite rural structure. Of the settlers at OTZEM, all of the 60 settlers' families came to Israel in May 1955 from the Atlas mountains of Morocco. They were from the same community and ethnically very homogeneous. This initial homogeneity was an important factor in understanding the settlement development. The background of the settlers was characterized by traits which were at odds with those required for optimal socialization to moshove life and the overall absorption into Israel society.

On the arrival of the settlers at the OTZEM settlement, they found small houses available for temporary accommodation, as well as small village facilities such as an office, a dispensary, a food store and a few classrooms, as well as the synagogue and Mikve (a ritual bath used by religious Jews). The settlement instructors, who were mostly volunteers from a veteran kibbutz, were already at the settlement. In comparison with the new immigrants from Morocco, the external change agents displayed different ethnic cultural traits; however, this seems to have been compensated for by their devotion and commitment. Sharing with the settlers their way of life was an essential part of their role and a source of pride for them. 
Type of Farming on the Settlement

Field crops were the basis for the farm type established for the OTZEM settlement and its surrounding villages was established on field crops. Crops included sugar beets, cotton, groundnuts, vegetable crops, and fruit orchards. Citrus, peach and apples orchards were established on a collective plot.

\section{Land Allocation}

Each of the 86 settlers received about 37 dunans ${ }^{*}$ in addition to their share in the collective plot of about 3,000 dunans. Vegetables were grown at first on the 3 dunans adjacent to the house and then increasingly on the larger plots (about 10-20 dunans).

\section{The Settlers' Income}

The average farm income rose from IL600 in the first year (1955-1956) to IL500,100 in 1964-1965. Total average annual net income rose from IL1,600 to IL5,100, and administered wages for farm and relief workers diminished from IL1,000 to IL100 in 1959-1960 (reported by Yaia Levi \& Gedalia Noveh).

Within nine years of the settlement's inception, the settlers had become responsible and hard-working. They came to be considered the vegetable suppliers of the area. They had gradually progressed along the steps set forth by the planning, namely, the termination of salaried labor in the administered farm; the shift from vegetable cultivation on the plot adjacent to the house to a combination of vegetable and other crops; taking over some of the local function tasks through the election of a village committee; and withdrawal of the external advisory team. Up until 1968, the OTZEM settlement was registered as a cooperative, and was the last among the

\footnotetext{
* Each dunan equals 250 meters; or 10 dunans equals 1 hectare.
} 
immigrant moshovim in the Lakhish region to achieving legal incorporation.

The withdrawal of the external advisory team and the regionalization of most of its functions prevented prolonged guidance The planners were served by having the village play an increasingly important role in the development of the area. However, this left OTZEM settlement insufficiently able to cope with two important factors: first, the challenge of new agricultural technologies, and second, ${ }^{* *}$ the exposure to over dependence on regional purchasing organizations.

In 1974 a plan for economic development was drawn up to diversify the farm structure of the settlement. The plan failed to generate a better local leadership or train people to be capable of coping with the requirements of more sophisticated credit and marketing operations. Farm specialization led to the formation of new pressure groups and disrupted the old homogeneity in the production. In the absence of adequate assistance and follow-up, the settlement was ill-prepared when it entered the areas of turkey and flower production, and consequently soon became overly dependent on the regional purchasing organization. This proved advantageous for a few of the most enterprising members and generated distrust in the village committee.

The settling authority of Israel set April 1, 1979 as the date for formal consolidation of OTZEM settlement. The phase of formal consolidation, a crucial one in the strategies of guided farm settlement, implied that an assessment be done of investments still to be made, in production factors for each holding according to the farm type, and taking into consideration investments already made. The date was to serve as a baseline estimating the value of the investment. On the signing of the consolidation contract, the

** 1 US\$ $=\mathbb{L} \quad 1-8$. 
settlers were considered sufficiently mature to make the best use of the investment and capable of refunding the loans on a long-term basis with easy rates of interest.

For the OTZEM settlement, the consolidation process of 1979 should have served as a continuation of the 1974 pre-consolidation; however, many elements contributed to a wide gap between the plan's intention and its implementation. The importance the gap was that it challenged the expectations of the average settler. Given inadequate information and preparation, he could have no clear idea of the criteria concerning the evaluation of his economic situation and the determination of investments. The settlers' attitudes were of anticipated well-being and economic strength, with little if any regard to the commitment expected of him. Such a situation was encouraged by the failure of the management committee to exercise effective social control.

\section{Participation in Production}

According to Moshav secretary estimates, only 12-15 settlers out of a total of 86 were fully engaged in farming. These were producers of vegetables for processing plants and export. Another 25-30 worked in agriculture either fully or on a part-time basis, mainly in fruit and vegetable production. More than half of the adult male population of the settlement were in nonagricultural employment or were unemployed on account of age, illness or even refusal to work, as in the case of many of the youth.

In the summer of 1982, the overall debt of the OTZEM settlement was about IL530 million, ${ }^{\dagger}$ and originated in part from losses in floriculture. Of a maximum of 15 producers of flowers in 1978-1979, four remained in 1982.

† 1527 - US \$1. (Cited by Jewish agency 1981) (?) 
A number of major externalities at the macro level lay under the overall crisis that afflicted the Israeli agricultural sector in the early 1980s. Included were diminishing returns on agricultural products due to international competition, and the change in Israeli development policies.

The capability of OTZEM settlement to rehabilitate itself through this or other programs depends largely on its ability, under proper guidance, to exploit its young labor potential, previously largely underutilized.

\section{Demography}

The OTZEM settlement was considered the third largest settlement of the Lakhish region, population 592. The average family size was 6-9 persons, the age group 15-29 made up 44.1 percent of the total male population. Of the 89 men comprising the 18-24 age group, 50 (56.2\%) were working outside their family farm, and $14(15.7 \%)$ were neither working or studying.

\section{NOAM SETTLEMENT}

The settlement is located on Beersheba Road and Even Shmuel. Noam is part of the Shafir Regional Council and is the regional housing center. It is about $3 \mathrm{~km}$ south of Kiryat Gat, a rural town of the Lakhish region, which offers a variety of commercial facilities. Kiryat Gat houses the regional organization, which provides the Noam settlement with accountancy services.

\section{Size of the Settlement}

Noam is smaller than OTZEM in both size and population. Its total area is 5,095 dunams, of which 2,859 are under irrigated agriculture and 2,236 are 
under the local cooperative as a single unit consisting of irrigated citrus trees (400 dunams) and rain fed cereal crops (1,848 dunams). The population between 1979-1980 was 503 people. Each of the 83 households had an average of 34.4 dunans.

\section{Noam Settlers}

All of the settlers of the settlement came from a common Moroccan origin. Despite their commonality, they displayed great heterogeneity in ethnic characteristics. There were three groups that came to the settlement. The first, 33 families of urban origin, arrived in August 1955. The second, 11 families from the Ta'anach Moshav settlement area in northern Israel, arrived in November 1955. From a small township in the Marakesh area, the third group, 12 families, arrived in April 1957. Such a mix led in time to repeated conflicts and an intricate web of alliances.

Because the internal unrest encouraged high turnover of external instructors, the department of community works introduced new modes of intervention for achieving the desired organizational outcome of the settlement. Such heterogeneity of background served as a stimulus to intergroup competition on the whole. The planned stage of salaried labor as a preparation towards the allocation of plots achieved the objective of the planners, in that it gave way to a gradual shift in the settlers from salaried worker to farm operator.

\section{Type of Settlement Production}

In the beginning, cotton, sugar beets and vegetables formed the entire production activity in the settlement. From 1968 on, turkey and dairy farming were gradually introduced. By 1970 there were 31 dairy farmers and 9 
turkey farmers, from a total of 47 households. The introduction of dairy production was done with the purpose of more diversified farm types.

The dairy production, however, did not come up to expectations, and by the end of 1974 , only three of the dairy farms were still in operation. Sugar beets declined until their cultivation was discontinued in 1971 . The returns from cooperative marketing of vegetables from 36 settlers declined by 94 percent. However, vegetable production for private markets continued, with smaller quantities and on less land. At the same time, new employment opportunities began to emerge in nearby places. These trends led to the liquidation of the dairy herds and shifts to turkey production as the most attractive product.

In 1980 the land settlement department declared Noam settlement ready for economic consolidation. The regional purchasing organization, which invested large sums of money in the construction of cow barns and turkey houses, started exerting pressure to bring about its implementation, as it had an interest in regaining its past investment in the financial allocations from the land settlement department.

The move toward economic consolidation met with strong opposition from the settlers. Many of the settlers saw non-cooperative marketing as a means of avoiding the control exerted by the regional purchasing organization on their defaulting accounts. The consolidation process was ignored by the settlers. The consequential struggle and the repeated impaired management led to an election five years later in 1976.

In 1981, the Noam settlement moved toward self-management. The long experience enabled the settlers to evaluate their past history with a new awareness of their potential. They learned that internal discord serves the establishment more than their own interests. During the 1981 political 
elections, the people of Noam settlement took revenge on their party by denying it their vote. Even so, they still felt heavily dependent on their party, particularly on the economic benefit afforded by the regional purchasing organization as well as welfare services.

FROM ADMINISTERED TO SELF-MANAGED COMMUNITIES: THE MODEL IN THE LAKHISH EXPERIENCE

The methods of settlement in Moshavi Olim and their management underwent a number of changes as a result of the experience gained during the establishment of settlement activities and supervision over them. At the beginning of mass settlement, in the years 1949-1952, no definite model was set for managing rural settlements. Ad hoc solutions were improvised by those responsible for the establishment and promotion of settlements. Only at a later stage, between 1954 and 1956, were organizational and administrative tools formulated which determined the administration of settlements. Studies and surveys conducted after that time revealed that the new methods were more adequate than the earlier ones, and allowed a speedier transition from administered communities to self-managed ones. These methods evolved mainly during the settlement of the Lachish region in the years 1955-1956. In the course of the settlement project, quite a few new Moshavin were established and occupied mainly with new immigrants from Africa and Asia, who came to Israel shortly before they settled in the Moshav and in most cases were brought to the Moshav directly upon arrival in Israel.

The administration methods applied in the Lakhish region were based on a number of stages which are described in the following. These together with a few other measures will be discussed later, enabled settlements to 
reach a certain degree of self-management within a shorter period of time than those that were established earlier and were not administered according to the new principles.

\section{Selection of Settlers}

The selection of settlers was minimal, and was based essentially on the age of the family in order to avoid settlement of older families who would be unable to work on the farm. The selected candidates were mostly young and middle-aged heads of families. Factors such as the health of family members, level of education, or professional training were not consider during selection. The lack of rigid selection led to the amassing of a large number of unsuitable settlers who could not adjust to rural life, and who finally had to leave the Moshav. The phenomenon of departure was therefore widespread in Moshavi Olim. There are no accurate data on the number of families that left, but estimates by the settlement department claim that of those referred to rural settlements between 1949-1954, about 30 percent either left or were expelled, whereas in 1955-1956, the figure dropped to about 16 percent, which was attributed to improvement in the selection process.

\section{The External Supporting Team}

In general, the new settlements were established as Moshavin. Village institutions never functioned as they should. No village committee was elected, and even when a committee of any village existed, it was ineffective. The daily administration and key positions were operated by the settlement department.

The outside people who lived in the village varied from settlement to settlement, but on the average, it included three instructors and two or three 
functionaries. The accepted models included a general instructor, extension worker, and home economics instructor

The job of the general instructor was to manage the village. He represented the Moshav in its relations with regional or national agencies, such as marketing and purchasing organizations, ministries and so on. $\mathrm{He}$ was in charge of interpreting the various development plans designed by the settlement department and explaining the basic principles of the Moshav to the settlers, and organizing elections to local institutions of the Moshov in order to gradually lead the settlers toward self-management. The instructor would operate primarily by serving as an advisor to the elected functionaries in key positions. The ability of the instructor to gain the confidence of settlers in general, and of the elected leadership in particular, played an important role in determining his success. The general instructor functioned as the channel for development between the settlement department and the Moshav; he therefore participated, together with his superiors in the settlement department, in the preparation of the annual budget. In the end, as long as the villagers were unable to manage the responsibility of administering their Moshav, the general instructor was the central organizing and managing figure in the village.

The main function of the extension worker, as any agricultural extension worker, was dispersing agricultural guidance to every settler in the settlement. Usually he was a graduate of agricultural school or an experienced farmer from a veteran agricultural settlement. He followed recommendations and directives formulated by regional branch experts. $\mathrm{He}$ was like the general instructor in that he operated in a way to enable settlers to gradually assume self-management of their own plots. 
The job of the home economics instructor included guiding the entire family, the housewife in particular, in the organization of the household, including budgeting of family expenses, setting up priorities for family consumer needs and advising on home maintenance. The home economics instructor played an important role for immigrants who located in the new settlements.

All three instructors were employees of the settlement department. In addition to the three major instructors, the external supporting team generally included two or three other workers. A kindergarten teacher, a nurse, and the local grocery manager. The kindergarten teacher was appointed and paid by the Ministry of Education, and the nurse was employed by Kupat Holim (the national health insurance organization). In some cases, the manager of the local grocery store was a private individual. Yet in most cases, the manager was a representative of the cooperative society that managed such groceries in Moshvi Olim.

The team's work in the Moshav was supervised by regional officers appointed for each of the regional units. The activities of the general instructor and home economics instructor were supervised mostly by the officers of the settlement, who were formally employees of its settlement department. Their role was to advise the instructors and to serve as intermediaries between them and the regional office of the settlement department. The extension workers on the other hand, were chosen and appointed by the department, and were in direct contact with the regional branch experts. 
STAGES IN THE TRANSITION FROM ADMINISTERED TO SELF-

\section{MANAGED COMMUNITY}

The settlement department defined a number of stages in the development of settlements toward self-management, which have been applied ever since the implementation of Lakhish project in 1955.

The stages represent a gradual process, both with regard to the agricultural training of settlers and in relation to management aspects, leading to self-administration of the settlement and proper functioning of the village institution and committees. This approach allowed the settlement department to spread the allocation of means of production over an extended period of time. The stages were not laid down as official regulations or procedures and therefore differed in each case. In general, the process was divided into three distinguishable stages: a stage of administration by external agencies; a stage of transition; and a stage of consolidation and weaning.

\section{Stage of Administration of External Agencies}

This stage usually lasted for three years following the establishment of the settlement. During this period, the agricultural branches were managed as an administered farm, and the various institutions were run by teams of instructors. In the first year the farmer did not receive any land for individual farming. In order to start the agricultural enterprise, a public company was founded by the settlement department affiliated with the Moshav, and all the village lands were handed over to it. The extension worker, together with a team of supervisors appointed by the public company, organized the work schedule, and the settlers worked as hired laborers and 
received a daily wage. This system allowed settlers to start working in agriculture without taking on themselves the risk attendant upon inexperience, their own or that of the settlement department, and without having to worry about the management of the farm.

During the first year only a relatively small part of the land earmarked for cultivation was actually tilled. The figures are different from one settlement to the other, but on the average about 10-20 percent of all the land allocated to a settlement was planted. The second year the settler was allocated an individual plot near his house, while the rest of the land was cultivated as before.

The third year, the area cultivated as one lot was much reduced, and the plots allocated to individuals for cultivation were extended, in most cases administered. Cultivation was terminated by the end of the third year, and areas were then allocated to the individual settlers.

\section{Stage of Transition}

The duration of transition varied in different settlements but usually lasted longer than the originally predicted period of 7-8 years set by the planners Settlements established in the Lakhish region in 1955 were supposed to undergo a transition stage lasting 5-6 years. In fact, this stage usually lasted for 10-12 years, but in some cases settlements were still at the stage of transition 25 years since their establishment. The reasons for this situation were mostly the lack of the necessary funds from the settlement department to accomplish the process.

\section{Stage of Consolidation and Weaning}

The consolidation stage of a settlement was reached when the settlement 
department, the settlement movements, and the settlers themselves all agreed that the settlement was ready to become independent of the regular care of the department. Once the decision was reached, the settlement department and the Moshav sign a consolidation contract. This contract, which is later also signed with every member of the Moshav, lists all the property, the equipment and means of production provided by the settlement department over the years, and states the terms for repayment of the loan. Thus upon entering the consolidation stage, each settler is to pay back the loan he received according to the defined conditions. The stage of consolidation and weaning usually lasted about three years.

The first group of 110 settlements from 300 Moshavim established between 1948-1960 reached the stage of consolidation in 1966. At the beginning of 1981, over 200 settlements reached the consolidation stage. Some 100 settlements still remained at the second stage 25 years since their establishment (Rokach 1988).

\section{CONCLUSION}

The stages of development and the management methods in the Moshavim that were established in Israel during the 1950s constituted a typical example of the weaning process in cooperative rural villages found in administered communities. Weaning was achieved by joint effort of several agencies and organizations, the settlement department of the Jewish agency, settlement movements, and regional organizations such as the regional purchasing organization and the regional councils. Without the integrated activity of all the organizations involved, the weaning process would probably have been longer and more difficult. 


\section{CHAPTER XI}

\section{LAND SETTLEMENTS IN INDONESIA}

Land settlements in Indonesia differ from the examples previously mentioned in this dissertation. Indonesian land settlements were implemented as a means to alleviate the population pressures existing on the island of Java. The directed movement of people from the island of Java to the outer islands of Indonesia proved to be one of the largest such movements in the world.

The movement of Indonesian people from Java to less populated islands dates back to the turn of the 20th century. The policy established to commence this movement was known as transmigration. At the turn of the century, Java's population accounted for nearly $80 \%$ of the Indonesia's total population. The tremendous population located in Java and corresponding evidence of declining rural social and economic welfare were two major contributing factors to the establishment of the transmigration policy.

\section{HISTORY OF TRANSMIGRATION POLICY}

The transmigration or settlements established by the government acted as nucleated communities and attracted unsponsored migration. The ultimate goal in transmigration was to set up a flow of spontaneous migrants who would move from overcrowded areas without government assistance. 
Such migration occurred on a large scale, especially in the provinces closet to Java. Spontaneous migration reinforced the official transmigration program, achieving its purposes at relatively little cost to the government.

Spontaneous migration accelerated the growth of settler communities and provided additional labor forces for clearing, planting, and other agricultural works. A few independent settlers arrived at the new communities from Java and Bali. During the 1970s the migration continued entirely independent of government support. The introduction of new, rapidly maturing varieties of rice, which produced three crops a year, produced higher incomes but also labor shortages. The higher incomes and labor shortages contributed to attract increasing numbers of not just farmers or farm laborers, but school teachers, shopkeepers, craftsmen, and others who found their services in demand. As economic growth throughout the nation increased during the 1970s there was a reverse flow of people from the outer islands to Java. Java was the center of the nation's new found growth in the 1970s and as such proved to be a substantial attractor of outer island settlers who were motivated by the employment opportunities and other benefits of city life.

To encourage the movement of people from Java to the outer islands, primarily Sumatra, the Indonesian government provided migrant families with free transportation and access to arable land which could be purchased using government loans. Government loans were also made available for building materials, tools and seeds. In Lampung, the province of Sumatra closest to Java, substantial investment in irrigation was made by the Indonesian government.

Between 1905 and 1922, nearly 22,000 people were moved to settlements in the southern Sumatra provinces of Lampung and Benghulu. In the 1920's 
the transmigration stopped, although there was some spontaneous migration to the Lampung settlements. In 1932 the colonial government of the Netherlands decided to resume transmigration. The needs of established settlers for harvest labor were met by bringing migrants to work for one season before becoming settlers themselves in new villages. By 1940 some 200,000 government sponsored migrants had settled in new villages under the Netherlands migration policy. During the 1930s a large spontaneous flow of migrant labor moved into the Sumatran plantations. In 1942 with the Japanese occupation, settlements came to an end.

For nearly fifteen years following World War II the Indonesian economy was racked by civil war and political instability. The Indonesian population continued to grow and manifest in congestion and poverty throughout Java and Bali. It was estimated that two-thirds of the nation's population lived below the poverty line. By 1966 economic development was given priority. The oil boom of the early 1970s provided Indonesia with resources for rapid economic growth.

\section{RENEWED INTEREST IN TRANSMIGRATION}

By the 1970s the change in government had restimulated interest in transmigration. Realizing that transmigration could not solve the problem of population imbalance, the government came to view it as a policy with a welfare objective. The objective was to raise the living standards of migrants as well as the standards of villages in Java. It was hoped that transmigration could serve as regional economic development on the outer islands.

During the 1973-74 and 1979-80 OPEC oil price increases, foreign exchange earnings were introduced to Indonesia. Large revenues went to the 
government which in turn identified development targets throughout the country. The transmigration policy became a main beneficiary. Both the scale of the transmigration program and its regional development objectives became more ambitious. The income of migrant settlers was raised by giving them enough land to grow cash crops as well as food for their own needs. Special emphasis was placed on tree crops such as rubber and oil palm.

Transmigration was accelerated to settlements that would benefit from the development of new infrastructure and community facilities such as schools, clinics, and water. The land settlements were to serve as growth centers by attracting spontaneous migrants from populated areas like Java. The land settlements would also serve to promote regional development beyond agriculture by diversifying to processing and manufacturing, as well as trade and services.

Major components of the transmigration and settlement policy included (1) selection of transmigrants; (2) selection of settlement sites; (3) land preparation; (4) migrant assistance; and (5) regional development.

\section{Selection of Transmigrants}

The selection of migrants involved three principles. Participation should be voluntary, only family units should be involved, and priority given to people from communities affected by natural disasters such as flooding or volcanic eruptions. The family head had to be 20 to 40 years of age and married with a family of not more than five members. No member of the household could be over 60 or under six months of age. Pregnant women were not allowed to participate with a family during migration. Farming skills were desirable but not necessary. As the program expanded in the 1970s officials started to stress the need to include migrants with skills that included 
building and construction

Finally, the migration was voluntary and therefore somewhat selfselective as the potential migrants were showing a willingness to leave their roots and face the risks of building a new life in unknown environments.

\section{Settlement Site Selection}

Selection of sites for transmigration settlements was based on two criteria; suitability for irrigation and proximity to Java. As the areas in south Sumatra and Lampung available for rice farming became threatened by population increases, attention shifted to other parts of the country for availability of good agricultural land. Much of the land in north Sumatra and south Sulawesi was already under cultivation. The choices left were between the relatively poor soils of the rain-fed upland and reclaimable swamp.

After 1966, the swamp reclamation alternative became the choice among transmigration planner. Nearly $1 / 4$ of the total Indonesian land area consisted of swamps. The swamp reclamation alternative appeared appropriate in part because food production was a priority objective and reclaimed swampland, with its tidal irrigation, was suitable for rice cultivation.

Swamp reclamation was pioneered in Indonesia by spontaneous migrants. Swamp reclamation for land settlements were made, under government auspices before and after World War II. These reclamation measures attracted few settlers.

With little opportunity for more settlement on irrigated lowlands, and swamp reclamation lagging, the transmigration program shifted its sights to locations in the rain-fed upland areas of the outer islands. The upland areas of the outer islands has some agricultural potential, but the soils were 
naturally low in fertility and highly susceptible to erosion. The upland areas were more suited to tree planting than crop cultivation.

In 1978, as part of a major reorganization of the transmigration program, responsibility for selection and evaluation of large sites was assigned to the Directorate of Regional and City Planning, with assistance from the World Bank. Soon thereafter, staff resources and appropriate procedures were developed.

Prior to clearing land, the newly reorganized transmigration program planned the selection of sites based on regional development criteria such as proximity to existing or proposed roads and regional growth centers. Sites were screened using existing data including aerial photography, topographic mapping, and soil surveys. These materials were analyzed to assess any potential blocks to accelerated settlement.

\section{Land Preparation}

The standard practice during the 1950s and 1960s was to give migrant families 2 hectares of land. One hectare was cleared by the government before the migrants arrived, while the other hectare was to be cleared by the settlers following their arrival. But clearing off the second hectare was not an easy job to accomplish. It often proved beyond the migrants' capabilities. Furthermore, the land cleared was only rain-fed which yielded a subsistence income at best.

In the 1970s, with the assistance of the World Bank, plots of $3.5-5.0$ hectares were allocated to each transmigrant family. The major portion of this land, including the 1 hectare cleared by the government, was reserved for tree crops. The government also assumed responsibility for provision of settlement infrastructure. In some instances the adequate preparation of sites, 
including soil surveys, clearing of land, construction of roads, and building of settler homes and community buildings took up to six years.

In 1978, the Directorate General of Transmigration was exclusively responsible for village planning, land clearing, and construction of houses and other village infrastructure. In the same year, village planning and land clearing were transferred to the new Directorate for Land Planning in the Department of Public Works. The new Directorate sought private contractors to clear the land. This action stimulated heated debate between the Indonesian government and the World Bank and affiliated consultants. Government agencies preferred mechanical clearing as an expedient manner to keep up with timetables. The World Bank preferred and advised use of manual techniques for clearing, citing soil conservation concerns and the prohibitive equipment costs associated with clearing small plots of land.

\section{Migrant Assistance}

The key factors to keep migrants in their new settlements was to provide them with other kinds of assistance besides land and housing. In the 1950s it was assumed that initial support to settlers such as seed and food allowances for a few months until the first crop was harvested was sufficient for the development of a successful settlement. This proved to be unrealistic, either because the land was not cleared when the settlers arrived or because the first crops were disappointing due to poor soil, inadequate water, or pests.

In the 1970s, the settlers received assistance during the first 12 month following their arrival. Under this plan the settlers had time to clear and cultivate their fields. The standard support consisted of monthly rations of rice and other household foods. Additionally, they received an initial supply of farming tools, fertilizer, pesticides, seeds and seedlings, and in some cases a 
draught animal. Failure to ensure that these essential supplies and services reached the settlers in a timely and proper manner proved to be a chronic logistical problem for the program.

One of the most effective forms of assistance to transmigrants was the promotion of tree crop planting. The World Bank provided financial and technical assistance in support of tree crop cultivation projects, chiefly rubber trees. The primary objective was to raise the income of settlers by growing cash crops instead of food crops.

\section{Regional Development}

The contribution of regional development to the nation of Indonesia resulting from the policy of transmigration in the outer islands of Indonesia, particularly Sumatra, Kalimantan, and Sulawesi was substantial.

Development of the primarily forested areas prompted movement of nearly 3 million settlers into new village communities and stimulated large scale rice cultivation. The program of transmigration contributed to the major policy goal of increased food production, as well as establishing the development of infrastructure items such as roads, irrigation and swamp reclamation. The program was also a contributing factor in the promotion of industry and trade, exploitation and processing of mineral, forest, and other resources. It also prompted the improvement of transportation and communications necessary to integrate the country more effectively into the national and world economy.

The outcomes of the program were less beneficial for the outer islands themselves. Members of settler families and spontaneous migrants initially attracted to the transmigrant settlements occasionally eased local labor supply problems for timber companies, and for small landholders and estate 
producers of cash crops. The roads built in association with transmigration improved market access for timber, cash crops, and processing industries. However, the major economic infusions to the outer islands weren't a result of the transmigration program. Instead, major industrial and economic developments in the outer islands through the 1970s came chiefly from oil and natural exploration and production.

\section{CONCLUSION}

Two serious constraints emerged in the transmigration program. The first being financial, the second, land availability. Most of the available land on the outer islands was unusable. It was either mountainous or swampland. What was available was often of poor soil quality or steep and subject to erosion and leaching. Aside from these basic land limitations, there were three factors which limited the land available for transmigration settlements. First, emerging national and international recognition of land conservation and rational exploitation of forest resources. Second, the native grasses which grew in the uplands were traditional obstacles to conventional agricultural production. Third, prior assertions to land claims by indigenous peoples of the region.

The financial constraints and the costly efforts to improve conditions for transmigrant via the provision of transportation, clearing and planting of settlement sites, housing, food rations, irrigation, road construction, health, education and welfare facilities, and expensive consultant services all conspired to increase the cost to the government per transmigrant family. Even with costs rising, the number of transmigrant families continued to increase. 
Until the 1980s the transmigration program and other national

economic and social development projects were supportable with Indonesia's oil revenue. The government began to recognize the competition between the transmigration program and other programs for limited resources. Some of the program costs were met by outside agencies such as the World Bank, the International Development Agency, and the United Nation's World Food Program. Indonesia has continued to struggle with funding the transmigration program as economic resources become constrained.

With all the commitment to the transmigration program showed by the Indonesian government over the years it would be unbelievable to recommend abandonment. The program has demonstrated the courage of policy makers and administrators to implement a scheme that is very capable of moving very large numbers of transmigrant families from Java to the outer islands. The program has also demonstrated support from the World Bank which provided technical assistance to address immense logistic and organizational problems.

There are problems, but with assistance, the program can address deficiencies in administration. Assistance can help bring new technologies to improve cropping patterns and animal husbandry. Developing new methods of planting and cultivating trees such as rubber, oil palm, and coconut may help to offset the low yields associated with the poor soils. Finally, technological assistance to eradicate indigenous grasses and make swamp reclamation less expensive could help to achieve one of the program's goals of generating more food. 


\section{CHAPTER XII}

\section{COMPARISON OF SETTLEMENT PROJECTS}

The discussion in this chapter will examine the policies and implementation of different resettlement projects and make an effort to understand the problems facing settlement programs in different countries, to understand the problems of what should or could have been done to improve the settlements and their settlers' well-being. There are some selective points of importance to be discussed, such as the performance of settlements concerning their objective achievements. Other important points include the the economic and social problems faced by settlements that affected their success or failure. Additionally, examine resettlement policies and their implications to determine if they were appropriate to solve the problems of poverty, unemployment and population redistribution.

\section{ACHIEVEMENT OF SETTLEMENT OBJECTIVE}

\section{Population Redistribution}

In Indonesia, such an idea was not new. The colonial Dutch tried it in 1905, but for economic reasons rather than to relieve population pressures. During independence, however, the process increased greatly between 1950 and 1977. A great number of the settlers moved independently throughout most of the period. The program was much more successful in meeting its 
targets following 1977. The target for the five-year plan (1979-84) was to move about 2 million people. It was not an easy task, but the government appeared to have achieved it. Encouraged by this success, the government wanted to move twice as many people in five years following 1984. However, relieving population pressure by moving people from Java to South Sumatra had only minimal impact because the population of Java increased by 35 million during the same period.

In Malaysia, while population redistribution was never an objective of land development programs, most settlers in Malaysia were from their own states because most states had a quota requiring a minimum of 50 percent of the settlers be from their own state. In this way projects succeed in retaining migrants from rural villages within the rural areas. Rural-rural migration is therefore encouraged, and thus minimizes rural-urban movement. This may shed some light on Malaysia's relatively slow rate of urbanization, compared with other developing countries.

\section{Settlements and Development of New Areas}

There are many reasons why a government develops an underdeveloped area: to increase agricultural production; provide land for landless or displaced people; relieve population pressures in overcrowded areas; or to make use of new areas for industrial or manufacturing development. Settlements are not then so much an end in themselves as a means of achieving other goals.

The pilot land settlement project in Iraq was intended to solve the land tenure problems in the southern reaches of the country. The outcomes were expected to improve the peasants' lives by increasing agricultural production and freeing them from landlord domination or control. Dujaila was very 
successful during its first years of existence. Agricultural yields were

promising and household incomes increased. Yet after the sixth year, the lands under cultivation in the Dujaila project developed a salinity problem that was beyond reclamation. Lack of a drainage system contributed to the demise of agricultural productivity in the Dujaila project, and ultimately to the failure of the intended goals of the land settlement scheme.

In the Philippines, the earliest settlement projects made use of the frontier area to achieve their objectives. The unexplored areas of Mindanao and the Cagayan Valley held potential resources that could be exploited. Furthermore, a belief permeated the philosophy of settlement development that an influx of Christian settlers into these regions would lead to the assimilation of cultural minorities. This was an important goal in the early settlement of the Mindanao regions.

The cultivation of unutilized land was also a major issue in parts of Africa. In Somalia, about two-thirds of the population was made up of nomadic tribes. Only 1.5 million of the 8 million hectares of land available for cultivation was actually cultivated. Three agricultural and three fisheries settlements were established to settle war refugees and the drought stricken population, but the achievement of these settlements were much below target. The original target laid down by the settlement development agency for developing agricultural land during the five-year plan of $1974-1978$ was 56,000 hectares. This target was scaled down to 30,000 hectares. During the next development plan of 1979 - 1981, the settlement development agency's objective was to develop 22,000 hectares. However, since 10,000 hectares of this was to be in the Dujuma area, the overall target was reduced to 12,000 hectares when the Dujuma project was abandoned at the end of 1980, because the land was found to be unsuitable for irrigated agriculture, and only small 
portions were suitable for rain-fed agriculture. Soon after, even this modest goal was further scaled down to 3050 hectares. The analysis of Somalia suggests that fisheries settlements were doing little better than the agricultural settlements, although neither appear to have been sufficiently successful in economic terms to be worth duplicating in future resettlement programs.

The settlement program in Ethiopia started after the 1974 drought. The goal was to settle about half a million people over a period of 10 years. By the end of 1983, only 103,500 persons had been settled in 83 settlements.

\section{Land for the Landless}

In Malaysia, the principal objective was to develop land for the landless and unemployed. In 1966 the government established an additional organization aside from the Federal Land Development Agency, called the Federal Land Consolidation and Rehabilitation Authority in order to assist other poor rural groups such as those with small and fragmented holdings. By the end of 1982, the Federal Land Development Agency had developed 331 projects with a total of 559,906 hectares of agricultural land, involving about 76,786 families.

\section{Regional Development}

Land settlement programs have sometimes been seen at least partly as a means of promoting regional development, Regional development includes the promotion of industry and trade, the exploration and processing of minerals, forestry and other natural resources, and improvement of transportation and communication necessary to integrate the region more effectively into the national economy. Such programs in land development 
for settlements seem too unrealistic. Land settlements are useful for the people who are given the opportunity to grow crops in somewhat better conditions than where they were before. Settlements may provide social relief for poor people but cannot contribute significantly to the industrial and commercial development of the region.

\section{Agricultural Development}

Agricultural development is considered one of the most important among the objectives of settlement programs. In Indonesia, the rate of productivity in the northern Sumatran area was been higher than that in southern Sumatra. In general, that productivity was low, except in the settlements that had tree crops or irrigated rice fields. None of the other settlements had returns anything like what the World Bank regards as the minimum feasible if the program is to be economically justifiable.

Settlement programs have not always been so unsuccessful in achieving their agricultural objectives. However, as I already reported before, the frontier migration in the Philippines was a major factor in increasing national agricultural output.

In Malaysia, land settlement projects made significant contributions to the development and diversification of agriculture, although land settlement in Malaysia created a small community of modern and relatively prosperous rubber and oil palm landholders. Established rubber and oil palm landholders appeared to play a significant role in making Malaysia the biggest producer of palm oil in the world.

The OTZEM settlement in Israel, with its vegetable and fruit production and processing plants for export, managed to keep about half the settlers engaged in agricultural production. 


\section{Improved Welfare of the Settlers}

The settlement projects in general in the developing countries had noble objectives: reducing poverty and raising the standard of living for those with inadequate holdings of land, the landless, refugees, drought victims, and war victims. It is thought that the settlements provided the settlers with better incomes and that the concentration of people into settlements made it easier to provide social services, such as housing, health care and education.

\section{Settler Incomes}

In Malaysia, it seems that rural farmers of any age who decided to join the Federal Land Development Authority settlements enjoyed, after a few years, steady increases in the level of their incomes compared with farmers of the same age who did not join the settlement schemes.

In Indonesia, the settlers seemed to experience some improvements in their incomes, although the evidence suggests that the benefits were on average relatively small.

\section{$\underline{\text { Social Services }}$}

In Tanzania, providing social services, such as clean water, education, and health services, to large numbers of the rural population was among the most notable achievements of the villagization schemes. Such services led to a reduction in mortality, a reduction in the incidence of some diseases, and implementation of technical and scientific innovation for social and economic development. Since independence, the enrollment rate in primary schools has almost tripled. One important social consequence of villagization has been the improved position of women in society. Women are entitled to 
village membership and play an active role in communal agriculture. The provision of clean water in many villages has relieved women from the hard task of carrying water from far distances to the villages.

In Somalia, income and production objectives were not met. But the settlements were quite successful in creating a social infrastructure that contributed to improved hygiene, nutrition, and education opportunities for large numbers of families.

\section{PROBLEMS CONFRONTING SETTLEMENT PROGRAMS}

\section{Abandonment of Settlement Projects}

When settlers were disappointed in their often unrealistically high expectations, with poor settlement performance and achievement of objectives, the tendency was for settlers to abandon the settlement and seek other opportunities elsewhere.

In Ethiopia, there was a high rate of settler abandonment, the reason being settlers were not allowed to bring in their families. This caused a shortage of labor and low productivity.

In Somalia, the productivity in settlements was so low the income of the settlers was below the target level and was not adequate. As a result, many of the settlers, especially the adult males, abandoned the settlements in search of work elsewhere, leaving behind the children and the older members of the families so that they could take advantage of the free education and the health and housing facilities available in the settlements.

In Indonesia, lack of facilities, such as housing, clean water, roads for marketing and scarcity of nonagricultural employment were among the important factors that led settlers to abandon the settlement projects. 
Lack of Nonagricultural Employment and Second Generation Problems

Non-farm employment is an area where most settlement projects seem to have failed totally. In Malaysia, where the land settlement programs were an integrated component of regional development, the problems were not solved. The size of the settlement plot was perhaps enough to provide a minimum existence for the family, if only family labor was utilized and the needs of the family small. However, as the family grows, the shortcomings of the small plot and it production potential become apparent. Malaysia had rigid principles that settler's land could not be subdivided, for small holdings were uneconomic. This meant the settler's dependents had to leave the land settlement to seek employment elsewhere.

In Israel, in the OTZEM settlement, half of its population were employed outside the settlement. Under such circumstances, what was needed was the establishment of urban-based industries and some kinds of activities in the settlement projects or nearby. This had not been achieved. Thus, although land settlement programs gave potential rural-urban migrants the alternative of remaining in the rural areas, they could play only a temporary role in combating rural-urban migration.

\section{Social Tensions Between Settlers and Original Populations}

Tensions could arise between two groups of people if the settlers are perceived to have more or bigger landholdings and better social services or to be encroaching on land traditionally farmed by the local community.

\section{Ecological problems}

Most such problems are seen in many Latin American countries*. The

\footnotetext{
* Latin American countries are not included in this study.
} 
practice of shifting cultivation by settlers have resulted in the excessive deforestation and serious ecological and climatic deterioration that occurred in the different basins of the forest highlands. In Peru, for example, during the period 1925-1984, approximately 7 million hectares of forest were destroyed. The cultivation of crops unsuitable to cleared forest also contributed to environmental problems. (Hyman 1984). 


\section{CHAPTER XIII}

\section{SETTLEMENT SUCCESS OR FAILURE}

The purpose of this chapter is to understand the performance of national resettlement projects in many Third World countries. The major focus of the discussion will be on the similarities and differences in the policies and implementation of different resettlement projects, to identify the problems facing settlement programs, and to understand what should or could be done to improve settlement outcome.

Lack of detailed and comprehensive planning was one of the most important factors contributing to poor performance of settlement programs. In the case of the Dujaila project in Iraq, there was no serious attention paid to preparing a master plan for the area or region. The project failed within six years. Settlements in Ethiopia and Somalia also suffered from a lack of planning. Because they were conceived during a period of national emergency, settlements usually tended to be created long before any social or economic planning was carried out.

In Ethiopia and Somalia things were done quickly, and ambitious and unrealistic goals were set to be achieved in far too short a time. The resettlement at Dujama in Somalia had to be abandoned five years after it was established because of the salinity of the soil. The same thing happened in the Dujaila project in Iraq, which had to be abandoned six years after it was started. 
The most important of factor of planning settlements was the suitability of the site. As mentioned above, the Dujuma project in Somalia and the Dujaila project in Iraq had to be abandoned after five and six years respectively because the salinity of the soil made them unsuitable for cultivation. Poor choice of sites was also a problem in Ethiopia.

There are many things as far as the selection of site that must be kept in mind. First, the physical condition must be appropriate; second, the soil should be in top condition and fertile; third, the rainfall must be adequate or there must be easy access to irrigation; fourth, the drainage system must be adequate. The settlement must be accessible to essential services as well as markets for the settlers' produce at production time. Settlement projects in many Third World countries have failed where these considerations have not been properly understood. In some cases, settlement sites were selected without prior studies of the quality of land or other considerations, such as rainfall and irrigation. Some settlements were in remote locations, near borders or in disturbed areas which faced serious security problems.

The size of the plot of the holding was a very important factor in attracting settlers. There were two main principles used in determining the settlers' plots: (1) the plot must be large enough to provide settlers with a better living than what they had in their area of origin, and; (2) the plot must not be larger than the settler can cultivate. Land or farm size must vary, however, with the type of crop, market conditions, soil management and technology available.

It is not a good policy to place settlers on a holding that does not provide them with the ability to change the number of dependents or produce enough food crop for their survival. A very small holding will not provide the necessary income; conversely, holdings that are too large will favor 
employment of non-family labor and most probably will result in the exploitation of permanent non-family labor.

Selection of settlers involves issues that are very complex and very important. The selection criteria depend on the national objectives. As some differ from one country to another, it is very difficult to provide a general standard of selection. One important thing that should be done is a clear explanation should be given to applicants at the time of selection of what will be expected of them and what they can expect in return, so that people do not come in with a misunderstanding of what the settlement project is all about.

An opportunity to be part of a settlement project often raises people's expectations even in successful settlements. This may contribute to settlement failure. Settlements in general require a major commitment from the settlers, but few families are prepared to wait 10 or more years for results that they feel should come immediately.

In some countries, the selection criteria was biased in favor of young people. Such conditions meant that villages in rural areas were losing energetic and young labor. Such migration effects of land development projects on the areas losing labor have yet to be studied.

The selection priority given to agriculturists with experience obviously had merit, though the principle need not be rigidly applied in all types of settlements. For example, where the chief objective of a resettlement is to resettle refugees or for national security, insistence on agricultural experience would be misplaced.

Some selection procedures were open to abuse. In Indonesia, little emphasis on agricultural experience has tended to serve as an excuse for including in transmigrant groups all kinds of unskilled and unwanted people. 
There were some merits in resettling people who speak the same language, belong to the same tribe, or come from the same background. It seems such an approach contributed to the minimization of social conflicts.

The selection preference for settlers with capital should also be assessed within the context of the overall objectives of resettlement. If, as in the majority of cases, land settlement schemes are designed specifically for the most disadvantaged of the population, then giving priority to those with capital conflicts with the overall intention. As far as the success or failure of individual settlers is concerned, of course, those with capital have a greater chance of success than those without. However, capital wealth is not the only prerequisite for a settler's success.

Land tenure defines the rights and obligations with respect to landholding and use of such land in agricultural settlements. The ideal land tenure system is one that provides adequate incentives to produce and to invest. It should afford reasonable income and security to those who farm the land. A good tenure system can also exist for generating adequate employment and promoting a more equal distribution of income.

In general, the approaches with which planners in different third world countries can create alternative tenure systems is greatly constrained by sociopolitical factors. Within these constraints, however, several general considerations apply. Equity and security are essential under any tenure system. Subdivision into uneconomic units should be strongly discouraged. Settlers must be aware of their rights and obligations, and the settlement authority must have the necessary enforcement authority. Settlers' rights over the land should carry a direct relationship to their contributions to land development. However, governments must impose some restrictions on the conditions of land titles; without such conditions, the settlers would either 
sell the land and thus become landless or subdivide the holding among their children and make the land uneconomic for production.

Good management is important in indicating a settlement's degree of success. Management is an integral part of the land development process, and implementation of it needs all the help and assistance of all government departments, especially the settlement agency.

To be successful, resettlement operations require a gradual transfer of responsibility from settlement agencies to the settlers. Otherwise, a relationship of dependency may occur, and all agency resources may become tied up in limited numbers of permanently supervised projects.

In many land settlement projects in Asia and Africa, dependency discourages self-mobilization and undermines the settlers' commitment to self-reliance and development and increases the costs of settlement. Care must be taken to avoid putting the thought in the minds of the settlers that they have become permanent wards of the state. This is an example of what happened in Somalia. There were fewer work incentives, and family incomes were not given adequate consideration. The settlement agencies have provided the settlers with all their basic needs. Similar problems have occurred in Ethiopia.

\section{PLANNED AND SPONTANEOUS SETTLEMENTS}

As noted earlier, planned settlements required a large degree of government involvement, including selection of settlers and types of services, and financial aid. In planned settlements, the questions is how much responsibility should be left to the individual settlers and how much should be guided by the settlement authority. The answer is very hard to 
determine. The ideal, of course, is to have both combined together, but it largely depends on the type of project and the types of crops to be produced. On the other hand, if the crops are grown for sale, and if the settlers' farms are to be economically viable, some central authority must organize all matters that are best done on a large scale, such as irrigation, mechanics operations, technical advice, processing and marketing of the crops, and purchase of supplies.

A study done by the World Bank in 1978 suggested that about two-thirds of the rate of rural land settlement was due to spontaneous settlement. Although spontaneous migration without government assistance is widespread, it does present problems of its own. Spontaneous settlements take a long time to become available, and unsupervised farming has a tendency to disregard proper land management and produces erosion and other environmental problems. However, in spite of the bad reputation of spontaneous settlement because of natural resource destruction, it does offer the best chance of success in developing new land where capital and administrative resources are scarce. 


\section{CHAPTER XIV}

\section{CONCLUSION}

Similar to the research done by Oberai (1988) and Levi (1988), my research into land settlement programs in some Third World countries has led me to believe the programs made no more than a modest contribution to the problems of population distribution, unemployment, and poverty. Very few settlements reached their objectives. Some increase in agricultural production and an improvement in settlers' standards of living was apparent in some countries. The overall impact on employment and production was limited.

Even with such limited success, land settlement programs are popular in many Third World countries because they are politically more desirable and easier to establish than other rural reform programs. While the cost per settler of successful settlements was high, even with government assistance, the total number of settlers involved in settlement projects has been small in comparison with the total number of any given nation's people in need of assistance.

To be successful, the planning and implementation of settlement projects requires a close look at the essential needs of the settlers. A very high priority should be given to providing community infrastructure and social services such as housing, schools, health care, and water supplies. Government help for housing should be limited to helping with site 
selection and planning, provision of building materials on credit, and technical assistance. This should help make settlers self-reliant and reduce the risk of creating dependent farmers.

When low productivity in settlements result in low incomes for the settlers, it is very important that the problems should be overcome by introduction of incentives. The provision of training and favorable prices for the settlers' goods, produce, and services would contribute to improved productivity. In some countries, as in Latin America, the practice of shifting cultivation by settlers and the resultant excessive deforestation are major factors contributing to the serious ecological deterioration that is being experienced in those countries. There is, thus, an urgent need to improve agricultural technology and to provide educational programs for the settlers covering various aspects of environmental protection.

Government plans to settle nomadic tribes must understand nomadic lives as a cultural system that has evolved over several centuries. From their movement, they derive not only subsistence, but the values and satisfaction of their particular way of life. The idea of settling them in agricultural areas at huge cost, therefore, needs to be reconsidered. In Somalia, for example, about one-third of nomad settlers have abandoned settlement projects.

Help for the nomads must first take the form of helping them to make better use of the resources they have, rather than attempting to settle them. This could be done by creating growth centers of attraction where they are provided with water, food, livestock feed, training, health and veterinary services, and other social services. This would reduce the radius of their movement, and as these centers of attraction grow in size, they would probably develop into settlements. Such a strategy is likely to be more successful and cost effective than a settlement program. Alternatively, a 
policy of encouraging voluntary, spontaneous settlement of nomads in regions where agricultural potential is greatest may be a more efficient alternative to planned settlement projects.

It is not sufficient, however, to look at settlements simply in terms of their agricultural potential. Purely agricultural settlements are inadequate for present day needs. Most settlement planners and implementers fail to give consideration in project design to generating non-farm employment, especially for settlers' children as they get older and enter into the labor force.

Land settlements should be planned within an integrated regional framework that includes development of related agro-industrial and service sectors. One country that has attempted to provide non-agricultural employment is the United Republic of Tanzania. Overall, settlement schemes suggest that resettlement should not simply move people physically from one region to another, but should embrace more concerted and imaginative planning and implementation strategies in the areas designated for settlement. Settlers must be provided with basic infrastructural facilities, and some improvement in income if they are to remain within a project.

There is a need to review the implementation strategies for new settlements based on the costs and benefits of alternative means of increasing agricultural production and achieving equitable distribution of land and incomes. Possibilities include intensification of cultivation and comprehensive land reforms. Even so, land settlement, spontaneous or directed, may well continue for reasons such as population distribution, accommodation of war refugees, and drought.

Land settlement should not be considered either as an end in itself or as a means of redistributing the population. It should be conceived as a strategy for creating viable communities. To be successful, the planning and 
implementation of settlements requires meeting the essential needs of the settlers and providing community infrastructure and social services, such as housing, schools, health care and water supplies.

Overall, settlement projects suggest that resettlement should not be simply physically moving people from one area to another, but rather should be more concerted in their planning The areas of destination should be more fully examined, accounting for basic human needs. Settlers must be provided with infrastructure facilities, roads, transportation, and improvement in income if they are to remain within the project. 


\section{REFERENCES CONSULTED}

Afzal, M. (1982) "Assistance to Demographic Analysis and Studies: Technical Progress Reports" Mogadishu: Central Statistical Department, Ministry of Planning.

Al-Haidari, Darwish (1950) "Dujaila" Iraq Journal of Agriculture, October, Baghdad.

Anderson, C. (1972) "The Latin American Political System" in The Political Economy of Development, N. Uphoff and W. Hchman, eds. Berkeley: University of California Press.

Arndt, H.W. (1981) "Survey of Recent Development" Bulletin of Indonesian Economic Studies 18, no. 3: 1-24, Canberra.

Arndt, H.W., and R.M. Sundrum (1977) "Transmigration: Land Settlement or Regional Development?" Bulletin of Indonesian Economic Studies 13, no. 3: 79-80, Canberra.

Asfaw, L. (1975) "The Role of State Domain in Ethiopia Agricultural Development" LTC no. 106, Land Tenure Center, University of Wisconsin.

Bahrin, T.S. (1968) "Land Development in Post-Independence Malaysia: Some Lessons" Geographica, vol. 4: 67-83.

(1979) "Development Planning: Land Settlement Policies and Practices in Southeast Asia" in Migration and Development in Southeast Asia: A Demographic Perspective, R.J. Pryor, ed. Kuala Lumpur: Oxford University Press.

Bahrin, T.S. and P.D.A. Perera (1977) "FELDA: 21 Years of Land Development" Kuala Lumpur, Ministry for Land and Regional Development.

Bahrin, T.S., P.D.A. Perera, and H.K. Lim (1977) "Land Development and Resettlement in Malaysia" University of Malaysia, Department of Geography. 
Boesen, J. (1979) "From Ujamaa to Villagization in Tanzania" in Towards Socialism in Tanzania, edited by B. Mwansasu and C. Pratt, pp. 125-144, Toronto: University of Toronto.

Braverman, A. and J.F. Stiglitz (1982) "Sharecropping and the Interlinking of Agrarian Markets" American Economic Review, vol. 72, pp. 695-715.

Buringh, P. (1966) "Water, Soil and Agriculture in Iraq" Nederlands-Arbische Kring 1955-1965, Eight Studies in Marking its First Decade, pp 1-10.

Cassanelli, Lee V. (1975) "The Sahelian Drought and its Demographic Implications" Washington, D.C.: Overseas Liaison Committee, American Council on Education.

Chan, P. (1983) "Population Distribution and Development Strategies in Peninsular Malaysia" in State Policies and Internal Migration: Studies in Market and Planned Economies, edited by A.S. Oberai.

Crisostomo, C. and R. Barker (1972) "Growth Rates of Philippine Agriculture, 1948-1969" Philippine Economic Journal, pp. 88-148.

Dumont, R. (1969) "Tanzanian Agriculture after the Arusha Declaration" Dares Salaam: Government Printers.

Ellman, A. (1970) "Progress, Problems and Prospects in Ujamaa Development in Tanzania" Economic Research Bureau paper 70-18, University of Dares Salaam mimeo.

Emmerson, D. (1974) The Bureaucracy in Indonesia. Cambridge: MIT, Center for International Studies.

Fisk, Brad (1951) "Dujaila Land Settlement" Journal of Geography, High Teacher College, Baghdad.

Gran, Guy (1983) Development by People: Citizen Construction of a Just World, New York: Praeger.

Hashim, Alladin (1980) "FEIDA's Continuing Development Tasks" Land Development Digest, 3, no. 1: 13-35.

Heegor, G. (1973) "Bureaucracy, Political Parties, and Political Development" World Politics, 25, no. 4. 
Hull, T.G. and I.B. Mantra (1981) "Indonesia's Changing Population" in The Indonesian Economy During the Soeharto Era, edited by A. Booth and P. McCowley, Kuala Lumur: Oxford University Press.

Hyden, G. (1980) Beyond Ujamaa: Under Development and an Uncaptured Peasantry, London: Heinemann.

James, W.E. (1983) "Settler Selection and Land Settlement Alternatives: New Evidence from the Philippines" in Economic Development and Cultural Change, Chicago: University of Chicago Press.

Kaplan, I. (1977) Area Handbook for Somalia, Washington, D.C.: U.S. Government Printing Office.

Kassaye, L. (1978) Organization and Management Manual for Special Settlement Schemes, Addis Ababa: Ministry of Agriculture and Settlement.

Kaufman, H. (1973) Administrative Feedback: Monitoring Subordinate Behavior. Washington, D.C.: Brookings Institution.

Lande, C. (1973) "Networks and Groups in Southeast Asia" American Politics Science Review, 67, no. 1.

Lebon, J.H.G. (1964) "Recent Research on the Land Potential of Iraq" Geography, R.54, pp. 104-109.

Levi, Yair and G. Naveh (1988) Toward Self-Management in New Land Settlement Projects: A Cross-National Study, Boulder, CO: Westview.

Maro, P.S. (1983) "Population Distribution and Density" Census Publications, Vol. 8: The Population of Tanzania 1978, edited by M. Rafia, pp. 91-109 Dares Salaam: Bureau of Statistics.

Maro, P.S. and W.F.I. Maro (1982) "Population Redistribution in Tanzania" in Redistribution in Africa, edited by J.I. Clark and L.A. Kosinski, London: Heinemann.

McCall, M. (1985) "Environmental and Agricultural Impacts of Tanzania's Villagization Programme" in Population and Development Projects in Africa, J.I. Clarke and L.A. Kosinski eds., Cambridge, England: University Press. 
McHenry, D.E. (1979) "Tanzania's Ujamaa Villages: The Implementation of a Rural Development Strategy" Berkeley: University of California, Institute of International Studies.

Mushi, S.S. (1971) "Ujamaa: Modernization by Traditionalization" Taamuli (Dares Salaam) 1, no. 2: 13-29.

Oberai, A.S., ed. (1988) Land Settlement Policies and Population Redistribution in the Third World Countries.

Omar, J. Mohamed (1977) "The Drought in the Semi-Desert of Somalia" in Conference on Alternative Strategies for Desert Development, Sacramento May 31-June 10, 1977, vol. 4, pp. 8-12, Davis, CA: University of California.

Paderanga, C. Jr., and E.M. Pernia (1983) "Economic Policies and Spatial and Urban Development: The Philippines Experience" Regional Development Dialogue (Nagoya) 4, no. 2: 67-86.

Pascual, E.M. (1966) "Internal Migration in the Philippines" First Conference of Population 1965, Quezon City: University of the Philippines Press.

Pelzo, K.I. (1945) "Pioneer Settlement in the Asiatic Tropics" New York: American Geographical Society.

Phillips, Doris G. (1959) "Rural-to-Urban Migration in Iraq" Economic Development and Cultural Change, vol. 7, pp. 405-421.

Powers, W.L. (1954) "Soil and Land Use Capabilities in Iraq: A Preliminary Report" Geographical Review, vol 44, pp. 373-380.

Renaud, B. (1981) National Urbanization Policies in Developing Countries, Baltimore, MD: Johns Hopkins University Press.

Rondinelli, Dennis A. (1983) Development Projects as Policy Experiments, New York: Methuen.

Rondinelli, D. and K Ruddle (1977) "Local Organization for Integrated Rural Development: Implementing Equity Policy in Developing Countries" in International Review of Administrative Science, vol. 1, no. 63, pp. 20-30.

(1978) Urbanization and Rural Development: A Spatial Policy $f$ or Equitable Growth, New York: Praeger. 
Scudder, T. (1981) "From Relief to Development: Some Comments on Refugee and Other Settlements in Somalia" Pasadena, CA: Institute for Development Anthropology.

Simkins, P.D. and F.I. Wernstedt (1968) "The Growth and Internal Migrations of the Philippine Population, 1948-1960" Journal of Tropical Geography (Singapore), vol. 17, pp. 197-202.

Simmons, John L. (1965) "Agricultural Development in Iraq: Planning and Management Failures" Middle East Journal, vol. 19, no. 2, pp. 129-228.

Simpson, G. (1975) "A Preliminary Survey of Settlement Projects in Ethiopia" Addis Ababa.

Weiner, M. (1962) The Politics of Scarcity. Chicago: University Press.

Wetterhall, H. (1972) "Government Land in Ethiopia: Draft Report" Addis Ababa: Ministry of Land Reform and Administration.

Wood, A.P. (1977) "Resettlement in Illubabor Province, Ethiopia" Ph.D. dissertation, University of Liverpool, England.

World Bank (1973) Philippine Agricultural Sector Survey, Washington, D.C.

(1977) Tanzania Basic Economic Report, Labour Market Allocation and Income Distribution, Annex 71, Washington, D.C.: International Bank for Reconstruction and Development

(1978) Agricultural Land Settlement, Washington, D.C.

(1980a) Project Summary of WFP Assisted Project Somalia 2294:

Resettlement of Nomads and Assistance to Refugees, Rome Food and Agriculture Organization of the United Nations.

(1980b) Report on Interim Evaluation of WFP Assisted Project Somalia 2294: Resettlement of Nomads as Farmers and Fishermen. Rome Food and Agriculture Organization of the United Nations. World Food Program.

(1983) Somalia: Agricultural Sector, 3 vols. Washington, D.C.: 